\title{
Article \\ Classification of Hot-Rolled Plates Using the Mahalanobis Distance of NMIs in Ti-Stabilized Austenitic Stainless-Steel Produced by Secondary Metallurgy
}

\author{
Franci Vode ${ }^{1, *}$, Franc Tehovnik ${ }^{1, *}$, Gorazd Kosec ${ }^{2}$ and Darja Steiner Petrovič ${ }^{1, *}$ \\ 1 Institute of Metals and Technology, Lepi pot 11, 1000 Ljubljana, Slovenia \\ 2 SIJ-Acroni d.o.o., Cesta Borisa Kidriča 44, 4270 Jesenice, Slovenia; gorazd.kosec@acroni.si \\ * Correspondence: franci.vode@imt.si (F.V.); franc.tehovnik@imt.si (F.T.); darja.steiner@imt.si (D.S.P.); \\ Tel.: +386-1-4701-800 (F.V. \& F.T. \& D.S.P.)
}

Citation: Vode, F.; Tehovnik, F.

Kosec, G.; Steiner Petrovič, D

Classification of Hot-Rolled Plates

Using the Mahalanobis Distance of

NMIs in Ti-Stabilized Austenitic

Stainless-Steel Produced by

Secondary Metallurgy. Materials 2022,

15, 684. https://doi.org/10.3390/

ma15020684

Received: 29 November 2021

Accepted: 14 January 2022

Published: 17 January 2022

Publisher's Note: MDPI stays neutral with regard to jurisdictional claims in published maps and institutional affiliations.

Copyright: (C) 2022 by the authors. Licensee MDPI, Basel, Switzerland. This article is an open access article distributed under the terms and conditions of the Creative Commons Attribution (CC BY) license (https:// creativecommons.org/licenses/by/ $4.0 /)$.

\begin{abstract}
Three charges of scrap-based, Ti-stabilized, Cr-Ni-Mo austenitic stainless steel in the form of hot-rolled steel plates were characterized. Based on automated metallographic analyses of representative microstructures, a quality characterization in terms of cleanliness of the hot-rolled steel plates was performed. Elevated contents of impurities, especially $\mathrm{Pb}, \mathrm{Bi}$, and oxygen, which affect the hot workability of stainless steels, were detected. The recycled FeTi-cored wire was the main source of the elevated levels of impurities detected in the hot-rolled, Ti-stabilized, stainless-steel plates. Related to this, elevated levels of nonmetallic inclusions (NMIs) and segregations were formed. The three charges were classified based on calculations of the Mahalanobis distance (MD) between the inclusions. The charge with the smallest number of nonmetallic inclusions was set as the reference class. The selection of outlier inclusions based on their MDs and their back-representation into ternary diagrams gave relevant metallurgical information about the abnormalities. The advantage of this technique is that the calculations of the MD and the threshold can be fully automated.
\end{abstract}

Keywords: stainless steel; ferrotitanium; impurities; oxygen; nonmetallic inclusions; scrap recycling; automated inclusion analysis; Mahalanobis distance

\section{Introduction}

The energy-intensive steel industry is responsible for approximately $25 \%$ of the global direct greenhouse-gas emissions [1,2]. Therefore, the key areas of the current research in process metallurgy relate to the circular economy (CE) and a reduction in carbon dioxide emissions [1-5]. CE as a concept of sustainable competitiveness involves the valorization of steelmaking leftovers for internal reuse (i.e., dusts, slags, sludge), enhanced steel scrap recycling, the use of secondary carbon carriers from nonsteel sectors as a reducing agent, and energy sources in the steelmaking process chain, as well as various business models with comprehensive supply chain analyses [3].

The production of new steel by recycling old steel requires up to 10 times less energy than the primary production of steel from iron ore [5]. As foreseen in the steel industry, electric arc furnace (EAF) steelmaking, either scrap-based or based on hydrogen-directreduced iron, will contribute substantially to the reduction of $\mathrm{CO}_{2}$ emissions [4]. However, there will still be a need to introduce carbon into the EAF process, either to carburize the steel or to create foaming slag to improve the energy efficiency of the steelmaking process. To develop a fully green steel using EAF, it will be necessary to use alternative carbon sources that are either renewable or circular (e.g., biomass, plastic, rubber wastes, etc.) [4].

Production starts with scrap remelting in EAF followed by secondary metallurgy [5]. For a wide variety of steel grades, intensive scrap-steel recycling in an EAF is already common practice [6-12]. Scrap is usually well sorted already by suppliers and typically has a low impurity content. On the other hand, when end-of-life (EOL) steel scrap is recycled, 
the different steel grades are generally separated according to main alloying elements $(\mathrm{Cr}, \mathrm{Ni}, \mathrm{Mo}$ ). Some nonferrous and nonmetallic contaminants (copper wires, aluminium, plastic from the shredding of cars, concrete residuals from demolition of buildings, etc.) are generally mixed in small quantities with the steel because of the imperfect separation of different materials prior to melting. Some impurities are removed as slag when the mixture is melted or during subsequent refining steps, and some elements evaporate, but some metallic elements cannot be simply removed (copper, lead). Consequently, the exploitation of steel scrap can lead to an overall increase in the impurity concentrations in steels that cannot be removed by metallurgical processes. Many problems are related to excessive levels of impurities that are prone to precipitation, segregation, and/or the formation of various complex nonmetallic inclusions [5-12]. Accordingly, studies that address open issues in scrap recycling are of great importance.

In modern steelmaking, the formation, characterization and control of nonmetallic inclusions are becoming increasingly important, and tailoring inclusions to improve the properties and performance of steels, known as inclusions engineering, is indispensable [13-18]. When cleaner steel is required, additional analysis methodologies and techniques are demanded. Metallographic and chemical analyses can be considered direct methods, while total oxygen content is used as an indirect measurement of inclusions to characterize steel's cleanliness in terms of oxide inclusions and assess the steelmaking process to control the steel's quality. Automated inclusion analyses are able to overcome several weaknesses of traditional measures [14]. Therefore, a combination of techniques is recommended [16-18].

Austenitic Cr-Ni-Mo stainless steels, which contain Mo to enhance pitting corrosion resistance, are used in the chemical and petrochemical industries; the food, pharmaceutical, and textile industries; building components; welding applications; and for tubes, boilers, vehicle tanks, etc. [19]. Modern steelmaking technologies have enabled the more economical removal of carbon from the steel, primarily through the development of argon oxygen decarburization (AOD) and vacuum oxygen decarburization (VOD). Both production methods lead to carbon levels below $0.03 \mathrm{wt}$. \% [20]. Grades with low carbon content are preferred for applications involving uses at elevated temperatures (such as welding), because chromium carbide precipitation is decreased or prevented and resistance to intergranular corrosion is increased [19]. Austenitic stainless steels can be stabilized using titanium to bind interstitial elements such as carbon and nitrogen to prevent the formation of chromium carbides and nitrides [21,22]. Titanium reduces intergranular corrosion and improves the weldability of corrosion-resistant $\mathrm{Cr}$-Ni steels [22,23]. The stabilized austenitic grades require a titanium addition of at least 5 times the carbon content or 4-6 times the sum of the carbon and nitrogen contents of the steel [24].

Initially, the role of the titanium added to steel as ferrotitanium was mainly to reduce the grain size and to act as a deoxidizer [25]. Titanium dissolved in steel is characterized by a high affinity for oxygen. Titanium lowers the activity of the oxygen in iron [22]. Since surface defects can occur on final steel products, control of the formation of oxide inclusions in Ti-bearing stainless steels is necessary. In addition, the deoxidation products can potentially form deposits within a submerged entry nozzle and thus clog the nozzle [26].

In steels, titanium is also highly reactive with carbon, nitrogen, and sulphur [27]. Nitrogen is an element that causes a great deal of concern. Since titanium nitride forms in preference to titanium carbide, based on thermodynamic considerations, it is essential (i) to add sufficient titanium to chemically bind the nitrogen first and then the carbon or (ii) to reduce the nitrogen as much as possible using other steelmaking techniques [27].

Titanium alloying can be made in the form of metal scrap, sponge, or as a ferrotitanium alloy. Ferrotitanium addition for binding interstitial elements is usually performed after the steel is refined in a ladle furnace (LF) [26]. For the cored wire, FeTi alloying is made as deep and late into the ladle as possible. Prior to the alloying, the liquid steel should be thoroughly deoxidized to reduce the oxidation of, and thus maximize the recovery of, the titanium [27]. In the case of titanium-stabilized stainless steels, the LF refining process involves deoxidation by $\mathrm{Al}$ followed by the addition of the Ti-alloy $[26,28,29]$. 
The quality requirements for FeTi wire are chemical composition, size, and cleanliness [21]. The levels of tolerable elements vary depending on the application. Usually, the Ti-Al-V (titanium, aluminium, vanadium) tolerances are defined. In addition, the maximum content of nitrogen, lead, bismuth, and tin are very important [27]. The phase composition of ferrotitanium depends on the content of Ti and impurities. The nature of the impurities that are present can be ascribed to different resources and processing routes [22,23].

With the increasing use of titanium alloys in various industries, e.g., in aerospace, shipbuilding, etc., large volumes of EOL titanium scrap are available and find a way as Ti-containing cored wires. Therefore, FeTi cleanliness has become an issue [27,30,31], and there is a strong demand for high-quality FeTi. Recently, a novel methodology was proposed for preparing low-oxygen, high-titanium ferroalloy from high-titanium slag and iron concentrate with a multistage and deep reduction procedure [32]. Moreover, the sustainable recycling of titanium scraps, along with a high-purity titanium production route via molten-salt electrolysis, was also proposed to separate the impurity elements and the titanium [33].

The aim of this study was to evaluate the influence of impurities on nonmetallic inclusion formation and the quality of hot-rolled plates manufactured from titanium-stabilized, austenitic stainless steels of AISI316Ti grade, i.e., from Cr-Ni-Mo steels produced by secondary metallurgy. In particular, the influence of the impurities present in a recycled ferrotitanium and the detected oxygen contents in the steel were highlighted. The metallographic results were compared and discussed with reference to the results obtained using mathematical modelling. NMI features obtained by automated metallographic analyses were employed to numerically estimate the quality of the hot-rolled plates. In the relevant scientific literature, NMIs are classified according to their type (carbides, nitrides, sulphides, oxides, etc.), and other, more complex inclusion types is a well-covered topic [6,7,9-11,13-18]. However, the use of NMI features for the detection of production abnormalities in terms of two-class classification has not been reported.

In the present study, the Mahalanobis distance (MD) was employed as a continuous measurement scale in a multidimensional system/space (NMI features in this case) between two classes of data [34,35]. The first class is used as a reference or normal class, and the second class (frequently abnormal) is compared against the first. The calculation of the MD is numerical and, from the user's point of view, undemanding and is therefore appropriate for automation [34,35].

The novelty of the study lay in the selection of inclusions based on their MDs outlying from the reference class. Inclusions classified as outliers are back-represented in ternary diagrams, thus giving relevant metallurgical information. The results were derived from a research collaboration between industry and a laboratory characterization of materials.

\section{Methods and Materials}

\subsection{Sampling}

For the chemical analyses, the steel samples were selected randomly.

For the metallographic analyses, the representative steel samples were selected using sampling in the longitudinal (i.e., rolling) direction. Steel samples taken from the hot-rolled plates are designated as Sample A, Sample B, and a reference Sample R.

Samples of recycled FeTi-cored wire were selected randomly.

\subsection{Chemical Analyses}

Chemical compositions of the materials under investigation were determined by an XRF analyser for the chemical analysis using a Thermo Scientific Niton XL3t GOLDD+ instrument (Niton Europe $\mathrm{GmbH}$, Munich, Germany) and an optical emission spectrometer with inductively coupled plasma (ICP-OES), an Agilent 720 instrument (Agilent Technologies, Inc., Santa Clara, CA, USA). 
The ICP-OES detection limits for $\mathrm{Pb}$ and $\mathrm{Bi}$ were greater than or equal to $0.01 \mathrm{wt}$. \%. Combustion methods using ELTRA analysers (ELTRA, GmbH, Haan, Germany), i.e., ELTRA CS-800 for carbon and sulphur and ELTRA ON-900 for oxygen and nitrogen, were also applied.

\subsubsection{Steels}

The $18 \mathrm{~mm}$-thick hot-rolled plates under investigation were industrially produced from Ti-stabilized, austenitic, Cr-Ni-Mo stainless steels. Their basic chemical compositions are listed in Table 1. In addition, the mechanical properties (i.e., impact toughness and hardness) of the steels were measured. The results are presented in Table 1.

Table 1. Characteristics of Ti-stabilized Cr-Ni-Mo steel plates under investigation.

\begin{tabular}{|c|c|c|c|c|c|c|c|c|c|c|c|}
\hline \multicolumn{12}{|c|}{ Chemical Composition/in wt. \% } \\
\hline Sample & $\mathrm{Cr}$ & $\mathrm{Ni}$ & Mo & $\mathrm{Ti}$ & $\mathrm{C}$ & $\mathrm{O}$ & $\mathrm{N}$ & S & $\mathrm{Pb}$ & $\mathrm{Bi}$ & $\mathrm{Fe}$ \\
\hline A & 17.1 & 10.7 & 2.1 & 0.4 & 0.041 & 0.0026 & 0.0104 & $<0.001$ & $<0.01$ & $<0.01$ & Bal. \\
\hline $\mathrm{B}$ & 17.1 & 10.7 & 2.1 & 0.3 & 0.024 & 0.0059 & 0.0104 & $<0.001$ & $<0.01$ & $<0.01$ & Bal. \\
\hline $\mathrm{R}$ & 17.0 & 11.9 & 2.1 & 0.3 & 0.049 & 0.0013 & 0.0080 & $<0.001$ & $<0.01$ & $<0.01$ & Bal. \\
\hline $\begin{array}{c}\text { Tolerance } \\
\text { wt. \% }\end{array}$ & \pm 0.2 & \pm 0.2 & \pm 0.05 & \pm 0.001 & \pm 0.003 & \pm 0.00002 & \pm 0.0005 & \pm 0.0005 & \pm 0.005 & \pm 0.005 & / \\
\hline
\end{tabular}

Charpy V-notch impact toughness/in J

\begin{tabular}{cccc}
\hline Sample & $25{ }^{\circ} \mathrm{C}$ & $-45^{\circ} \mathrm{C}$ & $-196^{\circ} \mathrm{C}$ \\
\hline A & $216.5 \pm 0.5$ & $219.0 \pm 1.0$ & $178.0 \pm 6.0$ \\
B & $264.0 \pm 0.0$ & $266.0 \pm 0.0$ & $212.0 \pm 2.0$ \\
R & $185.5 \pm 0.5$ & $163.5 \pm 0.5$ & $136.0 \pm 2.0$ \\
\hline
\end{tabular}

\begin{tabular}{cc}
\hline & Vickers hardness (HV10) \\
\hline A & $152 \pm 4$ \\
B & $150 \pm 12$ \\
R & $147 \pm 1$ \\
\hline
\end{tabular}

Differences in the mechanical properties of the steel plates were attributed to the differences in their chemical compositions.

Impact toughness was measured according to the international standard ISO 1481:2017. The standard specimens for the Charpy V-notch impact testing, of dimensions $10 \mathrm{~mm} \times 10 \mathrm{~mm} \times 55 \mathrm{~mm}$, were used for the measurements performed at $25^{\circ} \mathrm{C},-45^{\circ} \mathrm{C}$, and $-196{ }^{\circ} \mathrm{C}$. A pendulum impact tester MFL PSW 300 (MFL Prüf- und Meßsysteme $\mathrm{GmbH}$, Mannheim, Germany) was used.

The Vickers hardness (HV10) was measured according to the international standard ISO 6507-1:2018 using an Instron Wilson-Wolpert Tukon 2100B tester (Instron GmbH, Darmstadt, Germany).

\subsubsection{Cored Ferrotitanium Wire}

The chemical compositions of the recycled ferrotitanium (FeTi) wire used in the manufacturing of the Ti-stabilized, austenitic, Cr-Ni-Mo stainless steels are provided in Table 2. 
Table 2. Chemical compositions of the randomly selected samples of FeTi-cored wire (in wt. \%).

\begin{tabular}{ccccc}
\hline Element & Sample 1 & Sample 2 & Sample 3 & Tolerance/wt. \% \\
\hline $\mathrm{Al}$ & 2.7 & 3.1 & 3.2 & \pm 0.001 \\
$\mathrm{Bi}$ & 0.10 & 0.08 & 0.13 & \pm 0.005 \\
$\mathrm{Cr}$ & 0.38 & 0.35 & 0.34 & \pm 0.2 \\
$\mathrm{Fe}$ & 17.1 & 16.1 & 15.0 & \pm 0.2 \\
$\mathrm{Mn}$ & 0.10 & 0.14 & 0.09 & \pm 0.05 \\
$\mathrm{Mo}$ & 0.33 & 0.67 & 0.44 & \pm 0.05 \\
$\mathrm{Ni}$ & 0.42 & 0.55 & 0.39 & \pm 0.2 \\
$\mathrm{~Pb}$ & $<0.01$ & $<0.01$ & $<0.01$ & \pm 0.005 \\
$\mathrm{Sb}$ & $<0.01$ & $<0.01$ & $<0.01$ & \pm 0.005 \\
$\mathrm{Sn}$ & 0.21 & 0.24 & 0.34 & \pm 0.005 \\
$\mathrm{~V}$ & 1.9 & 1.7 & 2.0 & \pm 0.01 \\
$\mathrm{Zr}$ & 0.22 & 0.25 & 0.36 & \pm 0.005 \\
$\mathrm{Si}$ & 0.29 & 0.29 & 0.30 & \pm 0.02 \\
$\mathrm{C}$ & 0.17 & 0.16 & 0.17 & \pm 0.003 \\
$\mathrm{~S}$ & 0.009 & 0.010 & 0.010 & \pm 0.0005 \\
$\mathrm{~N}$ & 1.03 & 0.75 & 0.77 & \pm 0.005 \\
$\mathrm{O}$ & 2.02 & 1.47 & 2.06 & \pm 0.0005 \\
$\mathrm{Ti}$ & $\mathrm{Bal}$ & $\mathrm{Bal}$ & $\mathrm{Bal}$ & - \\
\hline
\end{tabular}

\subsection{Metallography}

The samples were ground and polished. Optical imaging was performed using an Microphot FXA (Nikon, Tokyo, Japan) optical microscope equipped with an Olympus DP73 camera (Olympus, Hamburg, Germany) and the Stream Motion Programme. Further metallographic analyses were performed using a scanning electron microscope with a ZEISS-Crossbeam 550/EDAX (Carl Zeiss AG, Oberkochen, Germany) instrument for the FE-SEM/BSE/EDS. In addition, a JEOL JSM-6500F (JEOL Ltd., Tokyo, Japan) scanning electron microscope was used for certain FE-SEM/EDS analyses. Where necessary, etching with the aqua regia etchant $\left(10 \mathrm{~mL} \mathrm{HNO}_{3}+30 \mathrm{~mL} \mathrm{HCl}+20 \mathrm{~mL}\right.$ glycerine $)$ was applied.

Automated Analysis of Inclusions

An automated quantitative and qualitative analysis of inclusions was performed by FE-SEM/BSE/FEATURE analyses using the JEOL JSM-6500F (JEOL Ltd., Tokyo, Japan) scanning electron microscope equipped with an Inca Energy 450 EDS system using an xsight LN2 (Oxford Instruments plc, Abingdon, UK) detector. For each sample, the analysed surface area was $2.0 \times 1.0 \mathrm{~mm}^{2}$ at a magnification of $2000 \times$. The applied electron beam conditions were a $15 \mathrm{kV}$ accelerating voltage and a $10 \mathrm{~mm}$ working distance. Images had a resolution of $1024 \times 832$ pixels.

In the automated FEATURE analysis, the detection size for the inclusions was set to be greater than or equal to 3 pixels (within the $0.12 \mu \mathrm{m}$ ECD bin size). This setting was capable of capturing relevant nonmetallic inclusions of the microstructure. According to the setting, FEATURE regarded various elemental segregations (generally of $10 \mu \mathrm{m}^{2}$ and more) as inclusions.

\subsection{Composition of Inclusions}

The compositions of the inclusions are graphically represented according to the elemental content in wt. \% based on data (i.e., measurements using the FE-SEM/EDS/FEATURE technique). MATLAB software was used (MATLAB, version R2016a, MathWorks, Inc., Natick, MA, USA).

\subsection{Calculation of the Mahalanobis Distance}

The calculations of the Mahalanobis distances (MDs) were performed according to [34,35]. The MD is a continuous measurement scale in a multidimensional system/space between only two classes of data, a reference (normal) and observed (abnormal) class. The MD is a 
vectorial-matrix equation and calculated as the distance between the centre of the normal class and each observation being evaluated. This takes into account the codependency of the data using a covariance matrix.

\section{Results}

\subsection{Microstructures of the Materials}

\subsubsection{Hot-Rolled Plates of Ti-Stabilized Cr-Ni-Mo Steel}

Typical microstructures of the hot-rolled plates in the rolling direction are shown in Figure 1. In the BSE imaging, heavier elements (higher Z) appear brighter than lighter elements. In the back-scattered electron images, the nitrides are very visible (Figure 1, see micrographs on the right-hand side). The nitrides typically appear with geometric angular shapes. Because $\mathrm{Ti}$ is a lighter element than $\mathrm{Fe}$, it is coloured darker than the iron matrix. Segregated elements are seen as darker (because lighter elements are present) or lighter stringers (containing heavier elements than Fe).
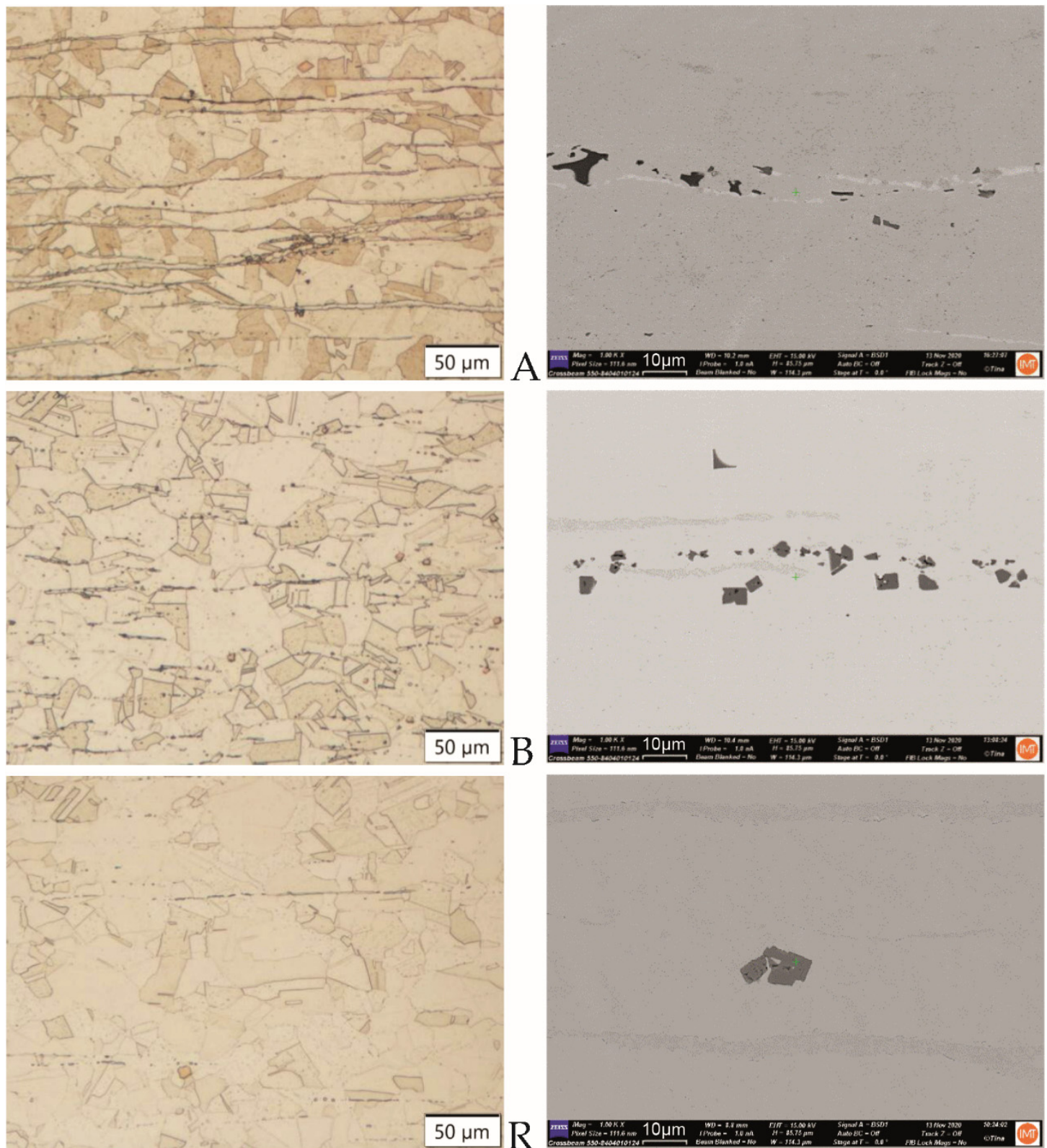

Figure 1. Microstructures of the hot-rolled plates A, B, and R in the rolling direction. (Left: OM, mag. $200 \times$, etched. Right: FE-SEM-BSI, $1000 \times$, polished). 


\subsubsection{Recycled FeTi-Cored Wire}

The recycled FeTi-cored wire that was used in the manufacturing of Ti-stabilized Cr-Ni-Mo steel demonstrated a very inhomogeneous microstructure and distribution of elements. In Figure 2, FE-SEM/EDS mapping of a randomly selected sample is shown. The material's inhomogeneity was previously confirmed by chemical analyses (Table 2).
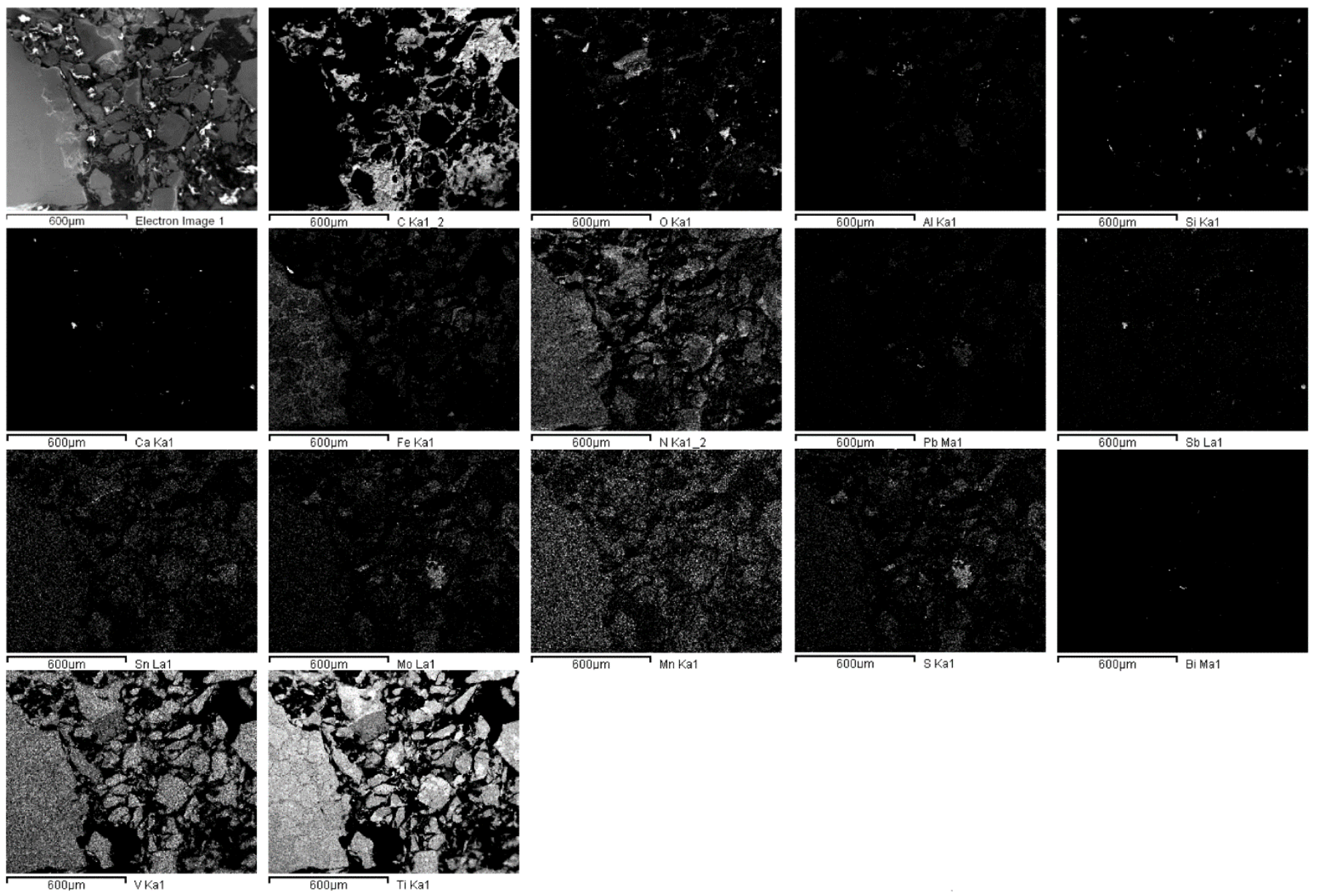

Figure 2. SEM image and the corresponding $\mathrm{X}$-ray elemental mappings showing the distribution of elements in the FeTi-cored wire (C, O, Al, Si, Ca, Fe, N, Pb, Sb, Sn, Mo, Mn, S, Bi, V, Ti).

\subsection{Automated Analysis of Inclusions}

3.2.1. Quantity, Size, and Composition of Inclusions Based on Data Obtained from Automated Analyses

FE-SEM/EDS/FEATURE analyses of the hot-rolled plates of Ti-stabilized Cr-Ni-Mo steel $A$ and $B$ and a reference sample $R$ were performed on cross-sections of the samples taken from the steel plates' rolling direction on populations of $15,858,16,705$, and 11,341 features, respectively.

The numbers of detected precipitates per area, which were the same for all the samples, should indicate the cleanliness of the steel.

With reference to this, the steel charge $\mathrm{R}$ was evaluated as a reference material in terms of the best cleanliness. The oxygen-rich sample B exhibited the lowest level of cleanliness.

Statistical analyses, the distribution of inclusions (i.e., nonmetallic inclusions), and segregations into size classes showed significant differences between charges (Figure 3 , Table 3). 


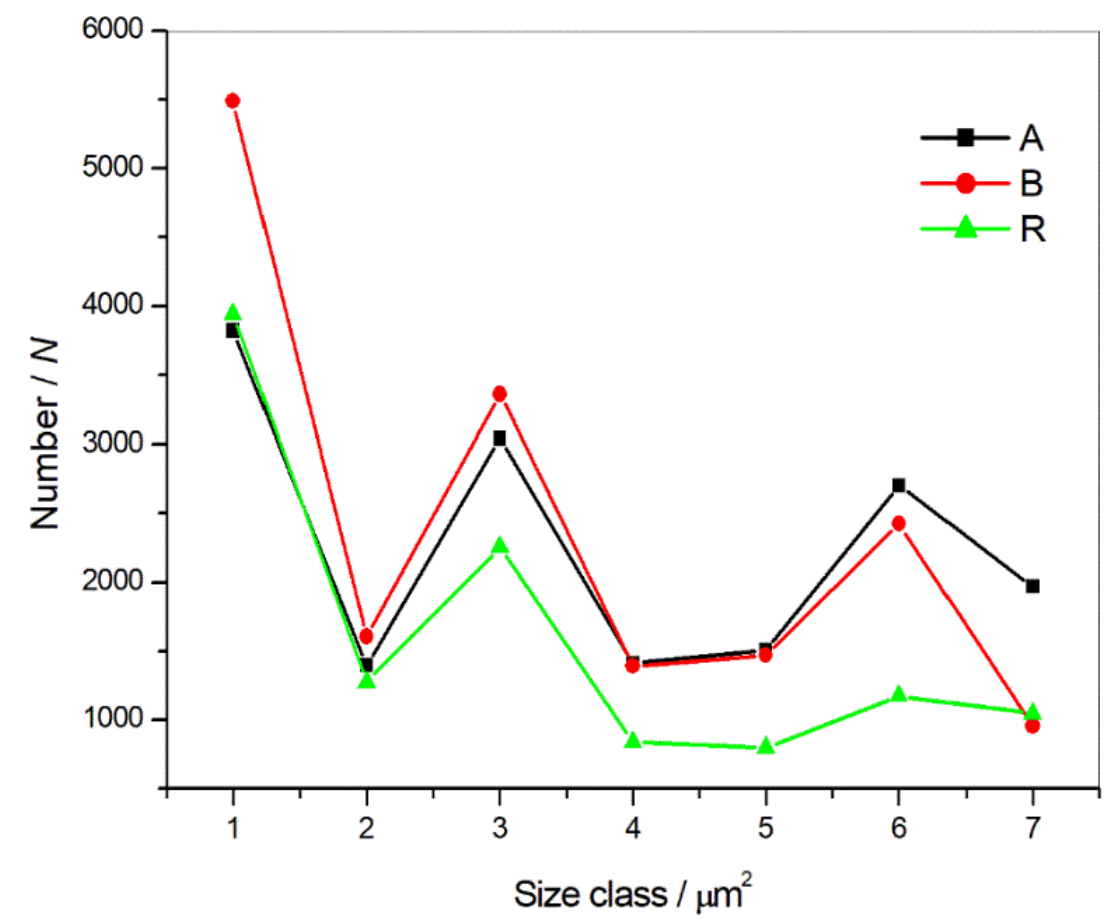

Figure 3. Number and size of inclusions in the hot-rolled steel plates A and B and the reference sample R.

Table 3. Number of detected inclusions in samples A and B and reference sample R and the size class, class frequency, and average size of these inclusions.

\begin{tabular}{cccc}
\hline & \multicolumn{2}{c}{ Class Frequency } & \\
\hline Size Class & Sample A & Sample B & Sample R \\
\hline $\mathbf{1}<0.015 \mu \mathrm{m}^{2}$ & 3824 & 5490 & 3943 \\
$0.015<\mathbf{2}<0.02 \mu \mathrm{m}^{2}$ & 1400 & 1607 & 1276 \\
$0.02<\mathbf{3}<0.03 \mu \mathrm{m}^{2}$ & 3043 & 3361 & 2259 \\
$0.03<\mathbf{4}<0.04 \mathrm{\mu m}^{2}$ & 1411 & 1393 & 839 \\
$0.04<\mathbf{5}<0.05 \boldsymbol{\mu m}^{2}$ & 1506 & 1471 & 799 \\
$0.05<\mathbf{6}<0.1 \mathrm{\mu m}^{2}$ & 2705 & 2425 & 1176 \\
$0.1<\mathbf{7}<200 \mu \mathrm{m}^{2}$ & 1969 & 958 & 1049 \\
Inclusions in total: & 15,858 & 16,705 & 11,341 \\
Average size of inclusions $/ \mu \mathrm{m}^{2}:$ & $0.20 \pm 2.36$ & $0.13 \pm 1.46$ & $0.25 \pm 2.54$ \\
\hline
\end{tabular}

The compositions of the inclusions containing the selected elements are represented in the ternary diagrams in Figures 4-6. 

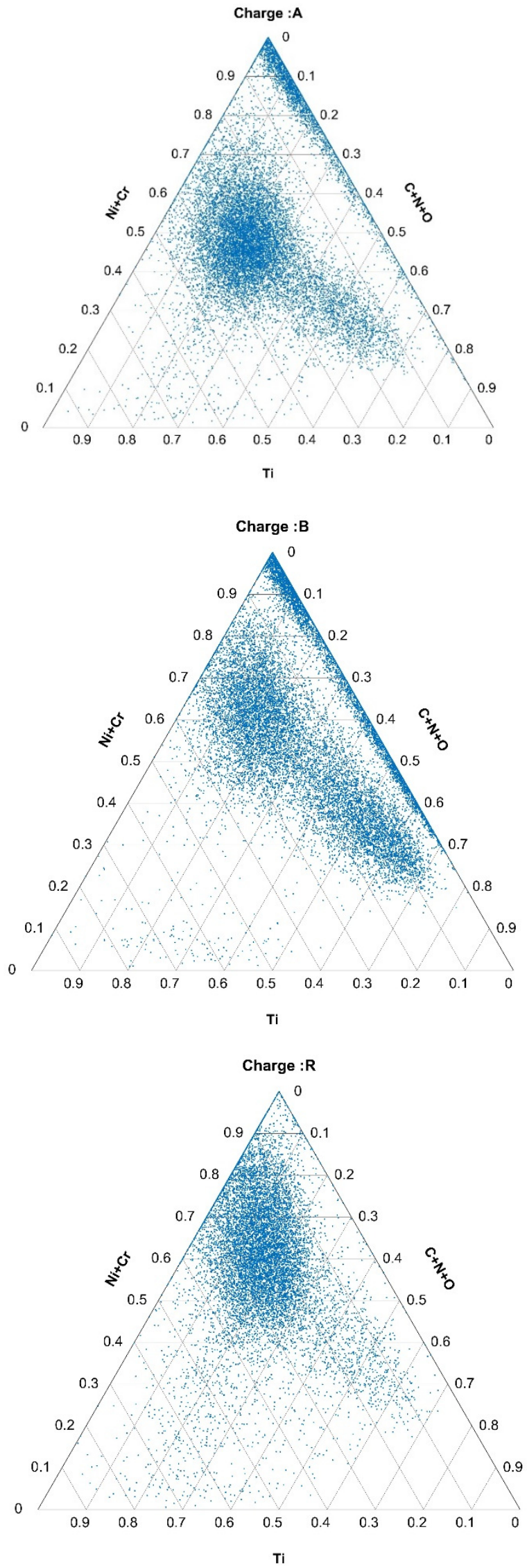

Figure 4. Composition of $\mathrm{Ti}-, \mathrm{C}+\mathrm{N}+\mathrm{O}-$, and $\mathrm{Ni}+\mathrm{Cr}$-rich inclusions in the hot-rolled plates of Tistabilized Cr-Ni-Mo steel A, B, and R. 

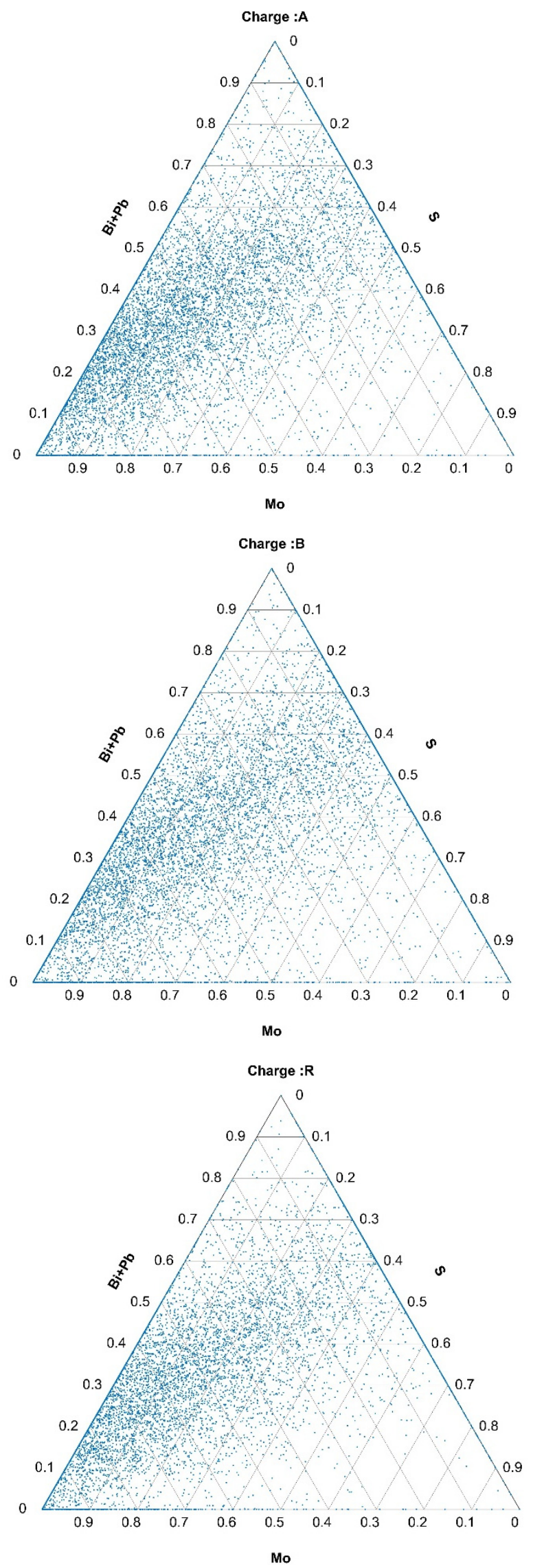

Figure 5. Composition of Mo-, $\mathrm{S}-$, and $\mathrm{Bi}+\mathrm{Pb}$-containing inclusions in hot-rolled plates of Ti-stabilized Cr-Ni-Mo steel A, B, and R. 

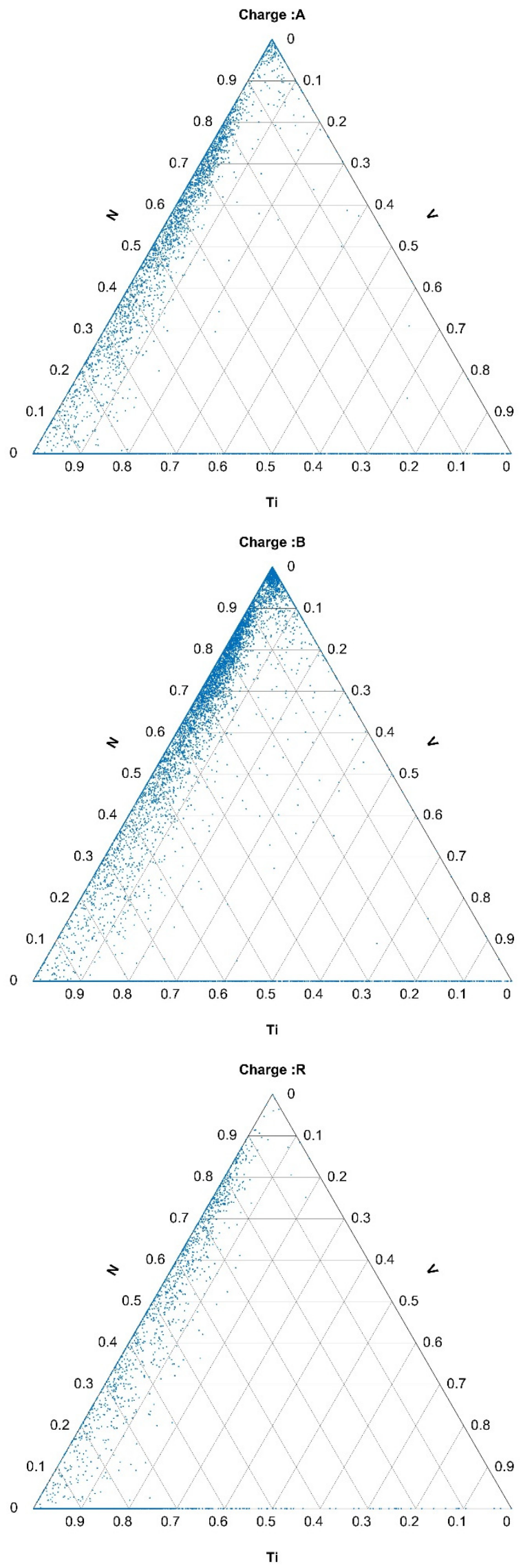

Figure 6. Composition of Ti-, $\mathrm{V}-$-, and N-containing inclusions in hot-rolled plates of Ti-stabilized Cr-Ni-Mo steel A, B, and R. 
3.2.2. Histograms of Calculated Mahalanobis Distances Based on the Data Obtained from the Automated Analysis of Inclusions for Charges A, B, and R

The different mean values of the MDs for charges $A, B$, and $R$ seemed to be the most obvious change besides the total number of inclusions (Figure 7). Another stand-out difference was the distribution of the MDs in charge A (above approximately 8); the MDs for charges $B$ and $R$ were significantly smaller above that value.
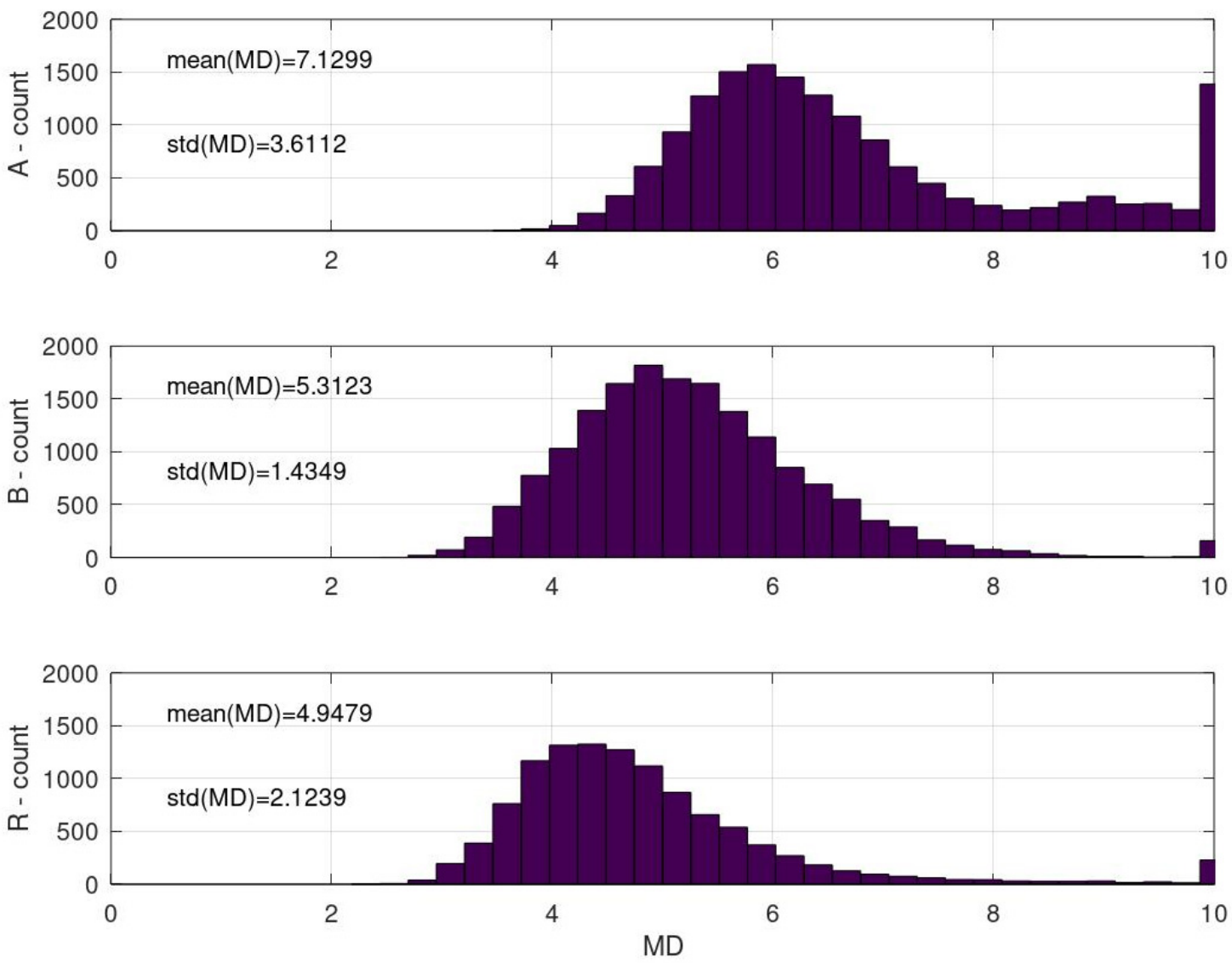

Figure 7. Calculated Mahalanobis distances between inclusions in the hot-rolled steel plates A and B and the reference sample $R$.

Note that the MD is a unitless measure. A survey of literature data on classification based on the MD suggested four thresholding methods [34,35]. Depending on the requirements and the overlapping of the observed classes, many different options for classifications are possible. In the case of the present study, classes of MDs for charges A, B, and R strongly overlapped, and every two-class separation resulted in a strong population of common inclusions of the two. However, one thresholding method, the probabilistic threshold method, is calculated as:

$$
M D_{\text {thresh }}=M D_{\text {mean }}+\sqrt{\frac{100}{100+\lambda-\omega}} s t d_{M D}
$$

where $M D_{\text {mean }}$ is the mean value and $s t d_{M D}$ is the standard deviation of the MD of the reference (normal) class. Lambda and omega are usually parameters of small values. In this case, both were assumed to be equal, thus leading to a value below square root equalling one. Consequently, the threshold was set at $M D_{\text {thresh }}=4.9479+2.1239=7.0718 \approx 7$.

Note that the threshold value can be easily obtained computationally. However, using human supervision, we preferred to set the threshold at the minimum of the MDA, slightly above 8 . 
Applying the obtained $M D_{\text {thresh }}$ to all three charges, $\mathrm{A}, \mathrm{B}$, and $\mathrm{R}$, ternary diagrams for the system of $(\mathrm{Ti})-(\mathrm{C}+\mathrm{N}+\mathrm{O})-(\mathrm{Ni}+\mathrm{Cr})$ for these nonmetallic inclusions, the thresholds of which were above $M D_{\text {thresh }}$, were plotted. Ternary diagrams for these inclusions for charges A, B, and R are shown in Figure 8. Interestingly, these inclusions were mostly bands with very low $\mathrm{Ti}$ contents and high contents of $\mathrm{Ni}+\mathrm{Cr}$, while the span of $\mathrm{C}+\mathrm{N}+\mathrm{O}$ for these inclusions was between 0 and 0.7 .

Analogous to these in Figures A1 and A2 are ternary diagrams for the inclusions of $\mathrm{Mo}, \mathrm{S}$, and $(\mathrm{Bi}+\mathrm{Pb})$ and for the inclusions of $\mathrm{Ti}, \mathrm{V}, \mathrm{N}$ (please see Appendix $\mathrm{A}$ ). In the case of the inclusions that contained $\mathrm{Mo}, \mathrm{S}, \mathrm{Bi}$, and $\mathrm{Pb}$, they were present in significantly larger proportions in charges $\mathrm{A}$ and $\mathrm{B}$ than in the reference charge $\mathrm{R}$. The same was valid for the $\mathrm{Ti}, \mathrm{V}$, and $\mathrm{N}$ inclusions.
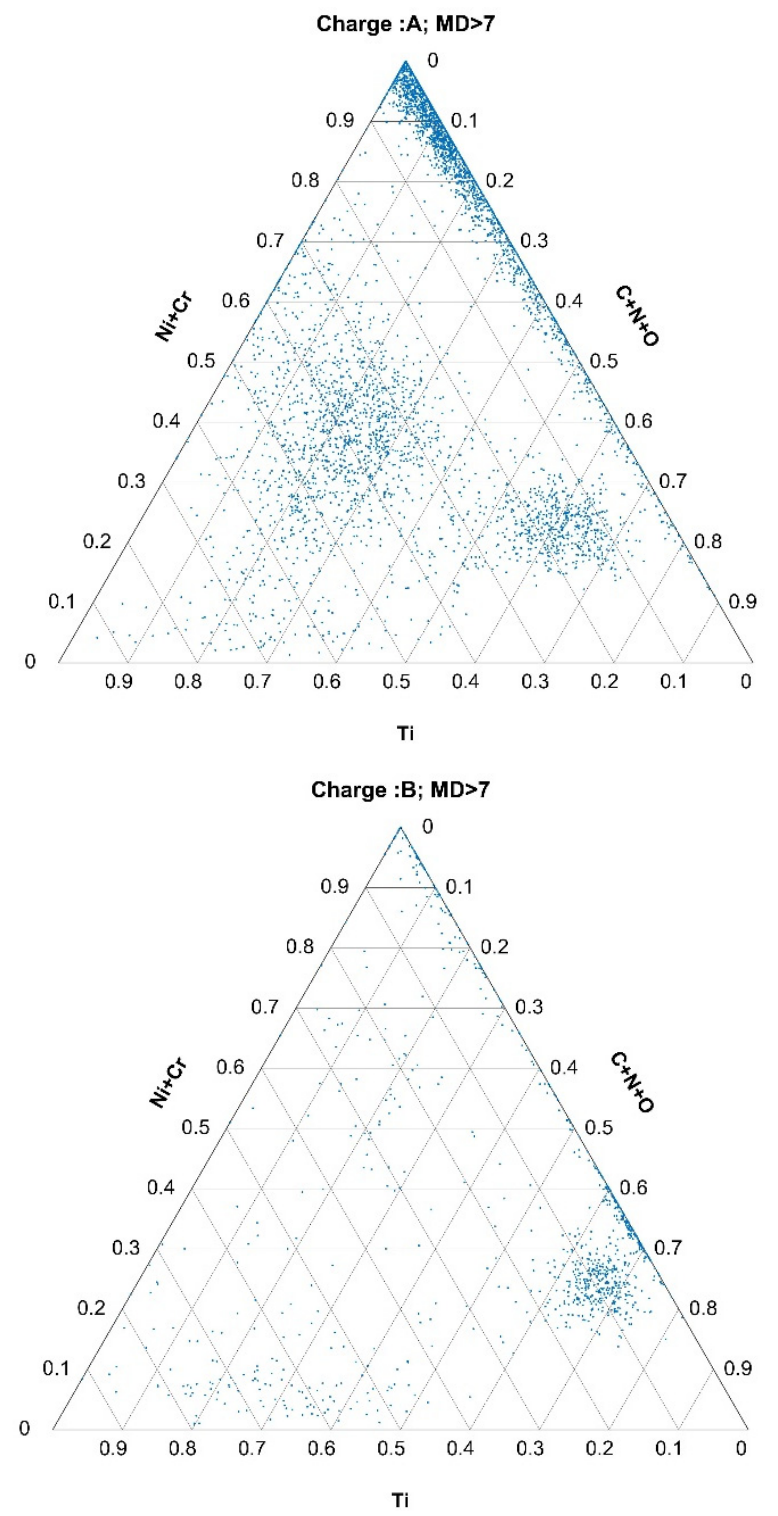

Figure 8. Cont. 


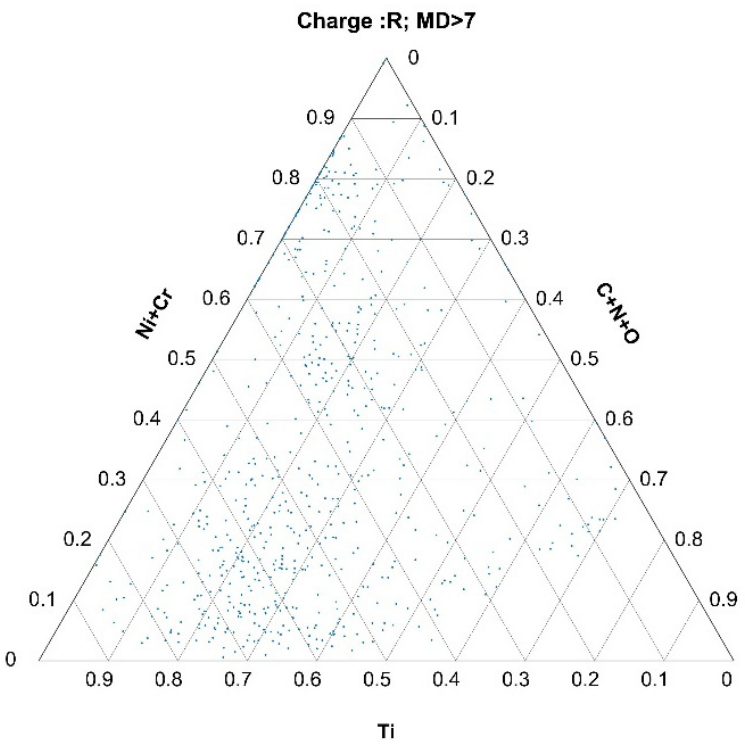

Figure 8. Inclusions classified as outlying $(\mathrm{MD}>7)$ represented in a ternary diagram of $\mathrm{Ti}, \mathrm{C}+\mathrm{N}+\mathrm{O}$, and $\mathrm{Ni}+\mathrm{Cr}$ for charges $\mathrm{A}, \mathrm{B}$, and $\mathrm{R}$.

\subsection{Formation of Nonmetallic Inclusions and Segregations}

3.3.1. Nonmetallic Inclusions after FeTi Alloying

Figure 9 shows the microstructure of steel B after alloying with FeTi wire. Large accumulations of impurities and oxygen were observed. Moreover, it is obvious that not only titanium but large amounts of additional impurities were introduced into the steel by alloying with a recycled FeTi (see the Ti, O, S, Mo, Bi, and Pb maps in Figure 2).
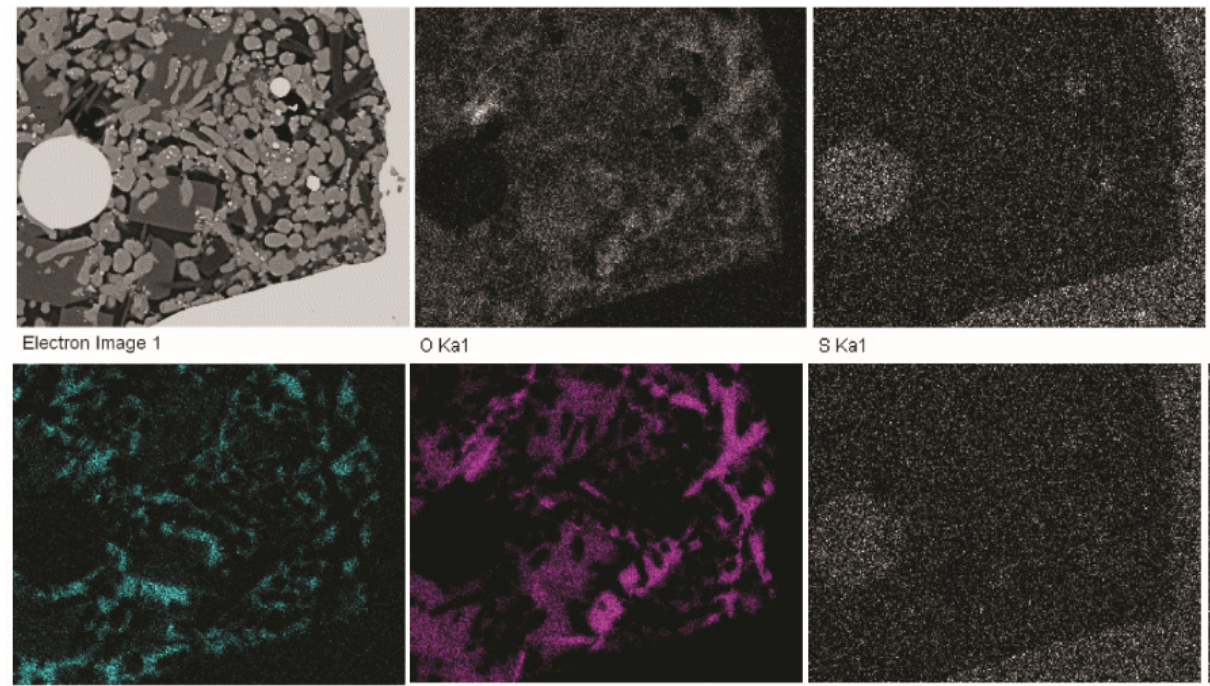

OKa1 SKa1
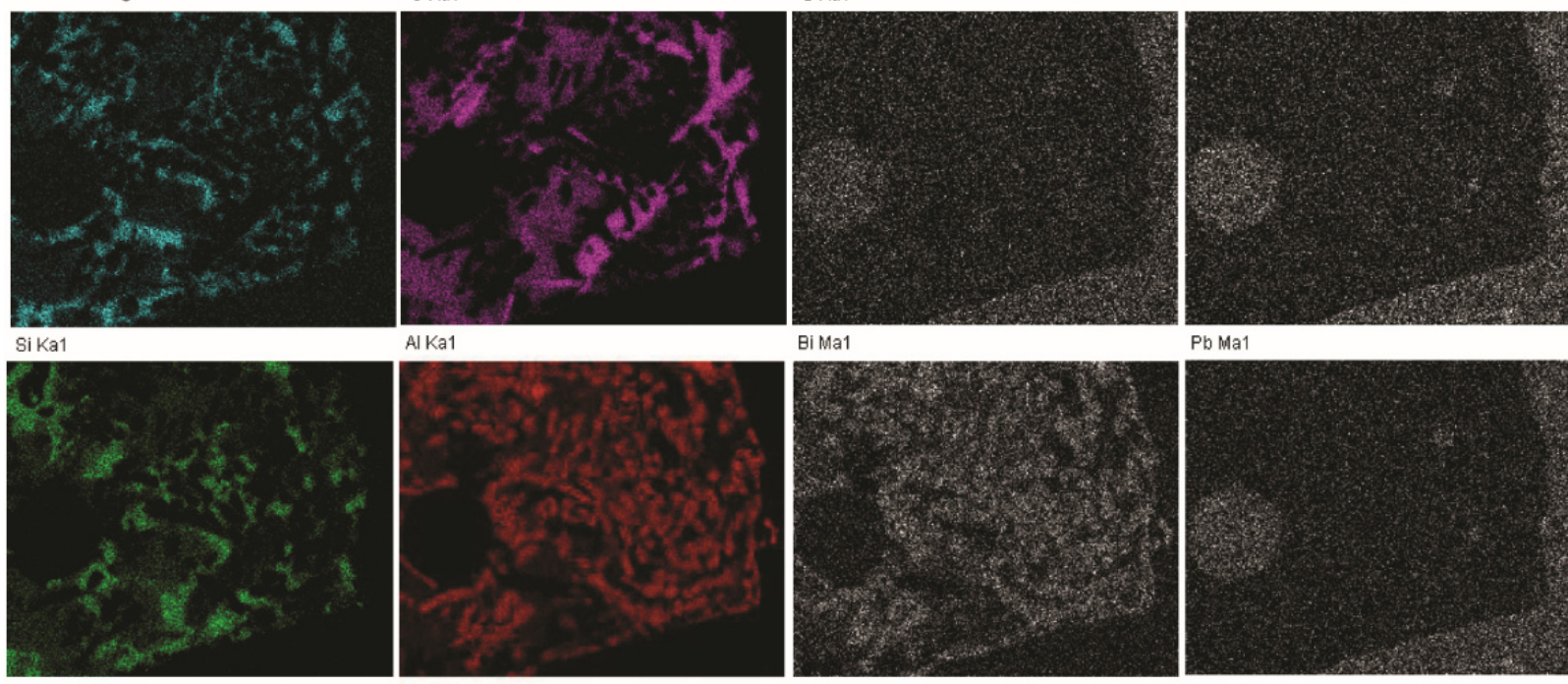

Al Ka1

Bi Ma1

$\mathrm{Pb}$ Ma1
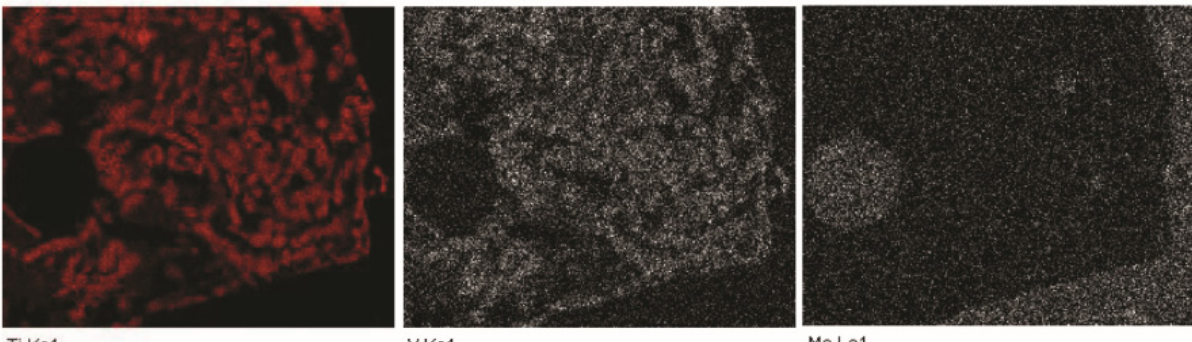

Mo La1

Figure 9. Accumulation of impurities in the steel melt $\mathrm{B}$ after FeTi alloying (FE-SEM-EDS; mag. $5000 \times$; SEI and the distributions of elements $\mathrm{O}, \mathrm{S}, \mathrm{Si}, \mathrm{Al}, \mathrm{Bi}, \mathrm{Pb}, \mathrm{Ca}, \mathrm{Ti}, \mathrm{V}, \mathrm{Mo}$ ). 
3.3.2. Nonmetallic Inclusions after FeTi Alloying and Hot Rolling

Segregation of Impurity Elements

Because of the nature of the chosen automated metallographic analytical technique, elemental segregations were also considered as nonmetallic inclusions. Figures 10-12 show the segregations of impurity elements in the analysed steels A, B, and R. In the EDS elemental mappings, $\mathrm{Cr}$ segregations were detected, as expected. More unexpected were the results showing the cosegregation of the impurity elements $\mathrm{Mo}, \mathrm{S}, \mathrm{Pb}$, and $\mathrm{Bi}$. This phenomenon was most pronounced in sample B and was not observed in the reference sample R.

Separate $\mathrm{Bi}$ and $\mathrm{Pb}$ enrichments were also found in the hot-rolled plate of steel $\mathrm{A}$ (Figure 13).

Based on the results (see Figures 2, 10, 11 and 13), it is most plausible that a recycled FeTi-cored wire was the main source of the elevated levels of impurities detected in the form of cosegregations.
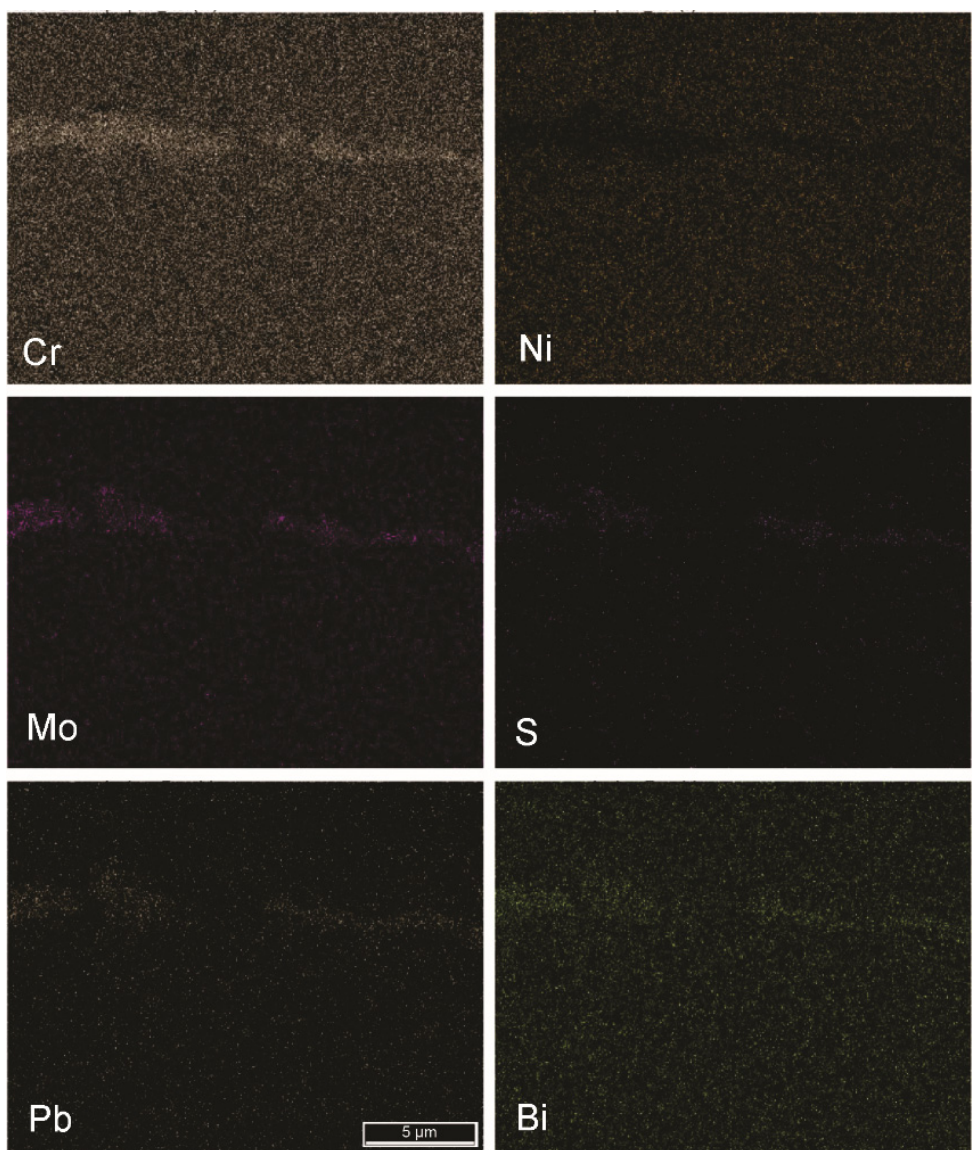

Figure 10. Segregation of $\mathrm{Cr}, \mathrm{Mo}, \mathrm{S}, \mathrm{Pb}$, and $\mathrm{Bi}$ in the hot-rolled plate of steel A (FE-SEM-EDS; mag. $5000 \times$ ). 

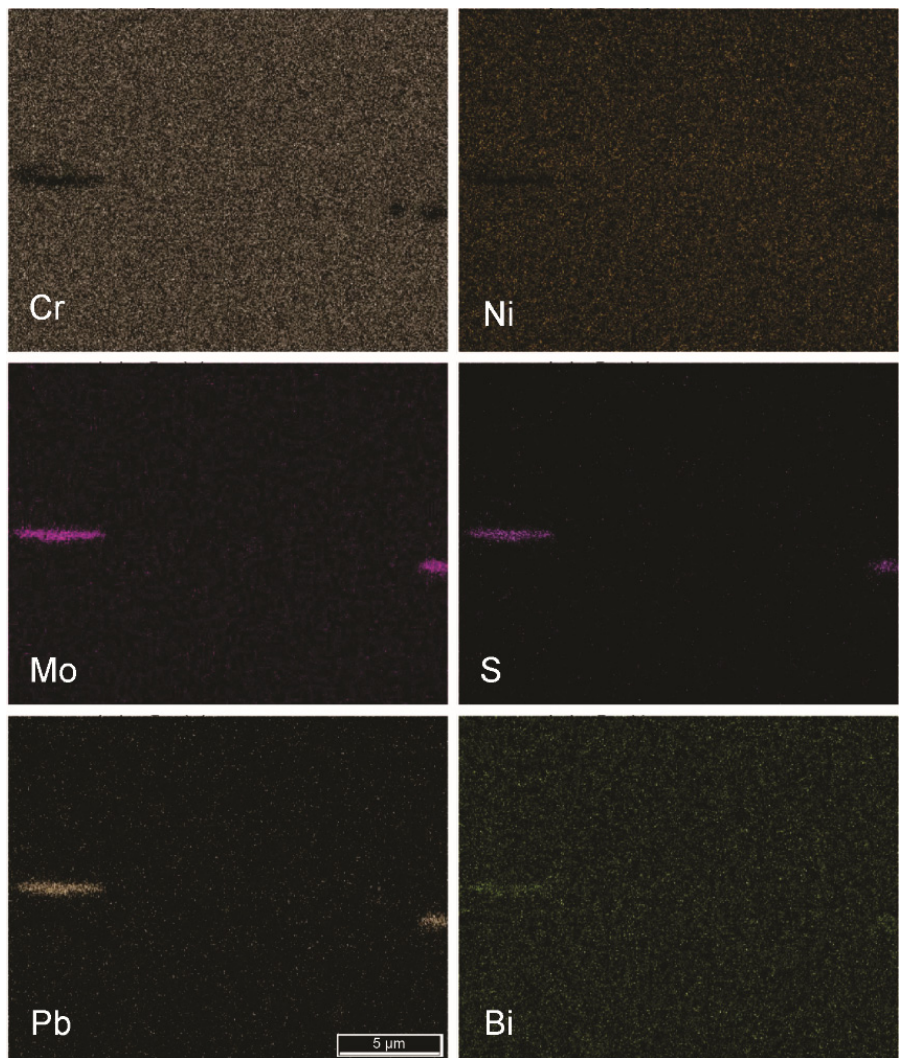

Figure 11. Segregation of $\mathrm{Mo}, \mathrm{S}, \mathrm{Pb}$, and $\mathrm{Bi}$ in the hot-rolled plate of steel $\mathrm{B}$ (FE-SEM-EDS mapping; mag. $5000 \times)$.

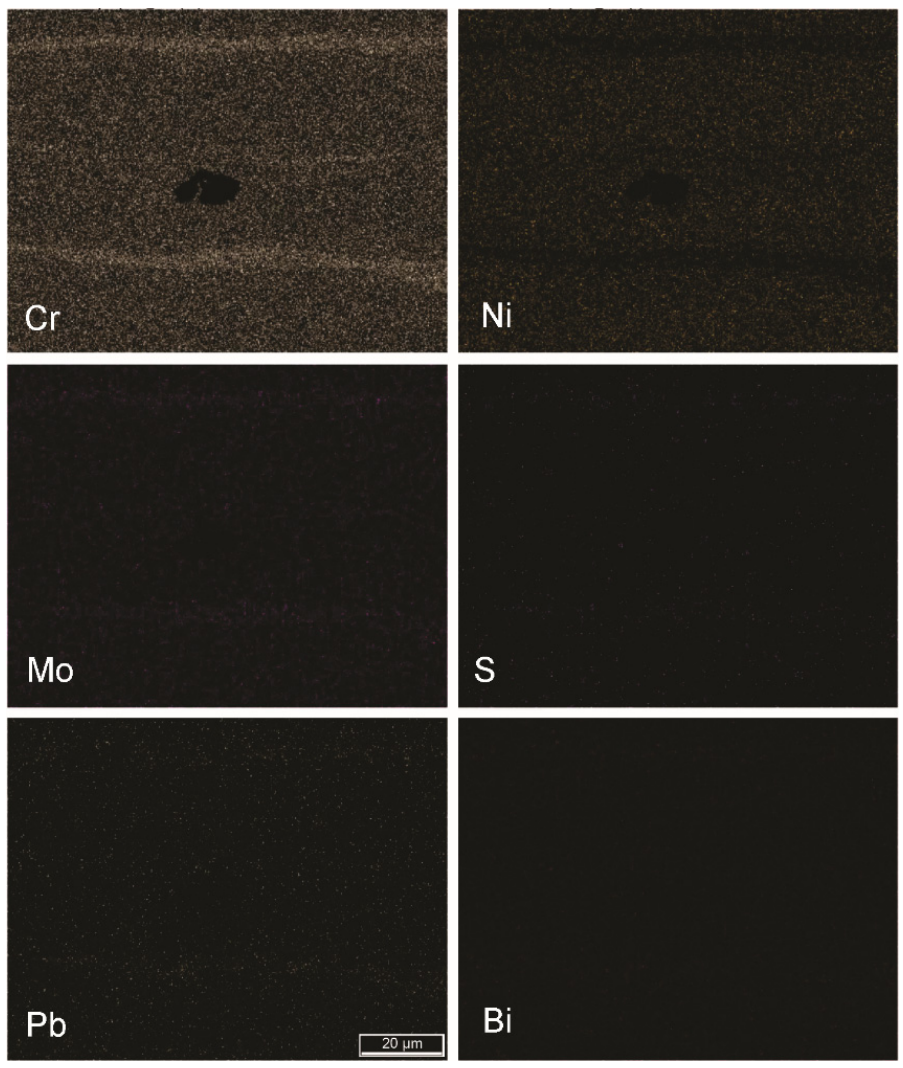

Figure 12. Segregation of $\mathrm{Cr}, \mathrm{Mo}, \mathrm{S}$, and $\mathrm{Pb}$ in the hot-rolled plate of steel $\mathrm{R}$ (FE-SEM-EDS mapping; mag. $1000 \times$ ). 

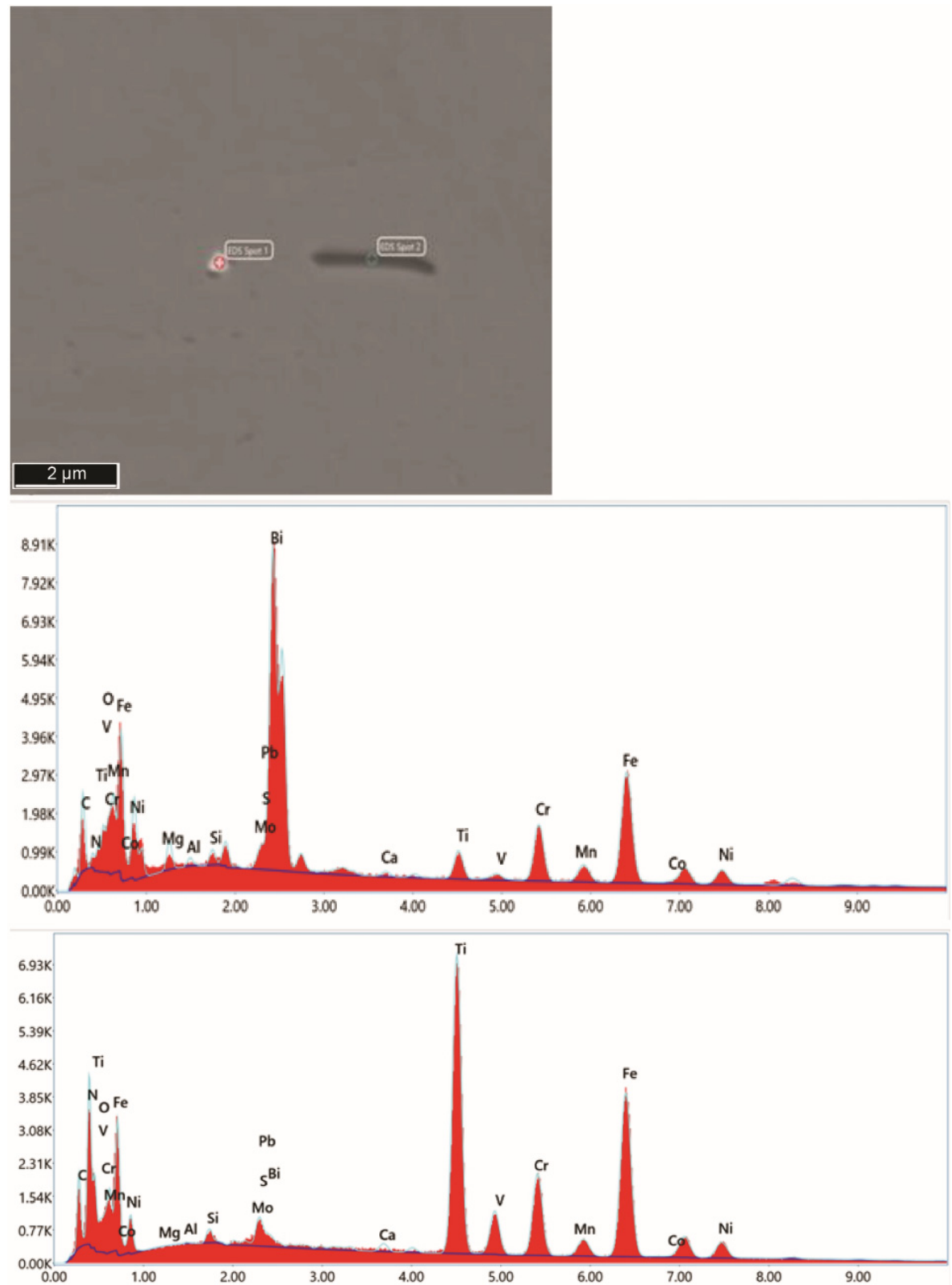

Figure 13. $\mathrm{Bi}$ and $\mathrm{Pb}$ enrichments in the hot-rolled plate of steel A (FE-SEM-EDS; mag. 10,000×).

\section{Discussion}

During the production of Ti-stabilized Cr-Ni-Mo austenitic stainless steel, the steel is stabilized by titanium. In the production of the steels under investigation, a recycled ferrotitanium-cored wire (FeTi) was used.

In representative microstructures of the analysed hot-rolled steel plates $\mathrm{A}, \mathrm{B}$, and $\mathrm{R}$, large accumulations of impurities and oxygen were observed. Moreover, it is obvious that not only Ti but large amounts of additional impurities were introduced into the steel by alloying using a recycled FeTi (see $\mathrm{Ti}, \mathrm{O}, \mathrm{S}, \mathrm{Mo}, \mathrm{Bi}$ and $\mathrm{Pb}$ maps in Figure 2). In addition, a considerable proportion of the volume was also represented by segregations of the impurity elements $\mathrm{Mo}, \mathrm{S}, \mathrm{Pb}$, and $\mathrm{Bi}$ cosegregations (Figures 10 and 11).

The quality requirements of the FeTi wire are its chemical composition, size, and cleanliness. The chemical compositions of the FeTi alloys are defined by the standard specifications for ferrotitanium, e.g., ASTM A324-08(2019), GOST 4760-91, etc. [22]. The tolerable levels of elements may vary. Usually, the Ti-Al-V tolerances are defined. In addition, the maximum contents of $\mathrm{N}, \mathrm{Pb}, \mathrm{Bi}$, and $\mathrm{Sn}$ are very important [22,27]. 
The cumulative content of impurity elements in the chemically very inhomogeneous FeTi-cored wire was relatively high (Table 2), and the contents of Bi, Sn, Al, V, and Mo were especially high. In addition, an increased value of $\mathrm{O}$ in the FeTi wire was confirmed by microchemical analysis. The average values of selected elements in the FeTi wire are provided in Table 4 . The proportion of insoluble Al was $0.18 \mathrm{wt}$. \%. This could have acted as a source of additional $\mathrm{O}$.

Table 4. Average values of the selected elements in the recycled FeTi-cored wire (wt. \%).

\begin{tabular}{ccccc}
\hline \% C & \% S & \% Al一Soluble & \% Al-Insoluble & \% Si \\
\hline $0.16 \pm 0.01$ & $0.01 \pm 0.001$ & $3.1 \pm 0.2$ & $0.18 \pm 0.03$ & $0.29 \pm 0.02$ \\
\hline
\end{tabular}

Based on the composition of the FeTi wire (see Tables 2 and 4), it is very likely that Ti6Al4V scrap was used (high proportion of $\mathrm{Al}$ and $\mathrm{V})$. Ti6Al4V is an $(\alpha+\beta)$ titanium alloy that is very commonly used in aviation [27]. The increased contents of $\mathrm{O}, \mathrm{C}, \mathrm{S}$ and Mo, however, were probably contaminants from the cutting process. $\mathrm{MoS}_{2}$ and graphite are often used as additives to lubricants in the cutting of Ti6Al4V and other titanium alloys. During the cutting process, $\mathrm{MoS}_{2}$ and graphite adhere to the Ti chips. This makes them very difficult to remove. It is also known that the chips oxidize during cutting.

In general, the Mo-S system is very important in extractive metallurgy [36]. Molybdenum disulphide $\left(\mathrm{MoS}_{2}\right)$ is widely used as a dry lubricant because of its low friction and robustness. According to the relevant literature [37], the presence of Bi impurities in $\mathrm{MoS}_{2}$ is confirmed to be in the form of bismuth oxide or sulphate compounds $\left(\mathrm{Bi}_{2} \mathrm{O}_{3} / \mathrm{Bi}_{2} \mathrm{O}_{5} / \mathrm{Bi}_{2}\left(\mathrm{SO}_{4}\right)_{3}\right)$. Bi impurities were also detected in elevated levels in the cored FeTi wire.

The presence of low-melting-point eutectic phases can initiate liquation cracking [38]. The hot cracking of steels is dependent on the levels of impurity elements. The impurities $\mathrm{S}$, $\mathrm{P}, \mathrm{Pb}, \mathrm{Bi}, \mathrm{Sn}$, and $\mathrm{Sb}$ affect the hot workability of stainless steels. S and $\mathrm{Pb}$ segregate to the phase and solidification grain boundaries where cracks appear during hot deformation [39]. Particularly in Ti-stabilized, fully austenitic stainless steels, various carbosulphides and eutectics in conjunction with $S, N$, and $C$ are deleterious [40].

The melting point of pure $\mathrm{Bi}$ is $271.4^{\circ} \mathrm{C}$. In a steel melt, Bi has a large local vapour pressure [41]. Moreover, $\mathrm{Bi}$ is well known to form morphologically diverse Bi-sulphides [42,43]. Most Bi particles adhere to preexisting sulphides in steel. Consequently, high Bi content in steel results in an increase in the number, average area, and average diameter of large-sized sulphide inclusions [43]. It was also reported that in austenitic stainless steels, additions of $(\mathrm{Bi}+\mathrm{Cu}+\mathrm{S})$ improve the steel's machinability and tensile properties [44]. However, the hot workability of Bi-bearing steels seems to depend greatly on the size, volume fraction, type, and distribution of the inclusions [45]. Low-melting-point Bi segregations can also be formed at austenite grain boundaries at 950-1100 ${ }^{\circ} \mathrm{C}[46,47]$.

Furthermore, it was reported that in the ternary $\mathrm{Bi}-\mathrm{Mo}-\mathrm{O}$ system, the following compounds can be formed [48]:

- $\mathrm{Bi}_{2}\left(\mathrm{SO}_{4}\right)_{3}$ with a melting point of $405^{\circ} \mathrm{C}$;

- $\mathrm{Bi}_{2} \mathrm{O}_{3}$ with a melting point of $817^{\circ} \mathrm{C}$;

- $\quad \mathrm{Bi}_{2} \mathrm{O}_{5}$, usually stable only in combination with $\mathrm{Bi}_{2} \mathrm{O}_{3}$ and not alone;

- $\quad$ in the ternary $\mathrm{Bi}-\mathrm{Mo}-\mathrm{O}$ system, the existence of several bismuth molybdates $\mathrm{Bi}_{\mathrm{x}} \mathrm{Mo}_{\mathrm{y}} \mathrm{O}_{\mathrm{z}}$ with melting points below $1000{ }^{\circ} \mathrm{C}$ is possible.

Steel production failures, in terms of inappropriate mechanical, chemical, thermal, or other properties of steel, are more or less regularly detected in ex post analyses.

However, a classification method based on a calculation of the Mahalanobis distance (MD) between the inclusions (i.e., nonmetallic inclusions and segregations) can be used to detect abnormalities. In this method, it is necessary to define all the deviations in terms of binarity (i.e., normal-abnormal). 
Although many material properties exhibit a continuous span, the standards for specific steel grades determine the limit values and can thus also be considered as binary (normal vs. abnormal). On the other hand, many properties such as surface defects, cracks, etc. are inherently binary (normal vs. abnormal). The remaining production without detected defects or within the specified tolerances can be considered as the normal production class. Using thresholding of the MDs, we could use the MD as a predictive classification model, although with some precautions and limited predictive accuracy [35]. Nevertheless, the MD has found various applications [34]. MD is used to construct a continuous measurement scale to discriminate observations and measure the level of abnormality of abnormal observations that are compared to a group of normal observations [34].

The MD, as a measure of the difference between only two classes, offers some possibilities for the automatic detection of anomalies in steel measured indirectly using data obtained with the automatic detection of nonmetallic inclusions. Since the MD is by nature a comparative method, the data obtained (automatic detection of nonmetallic inclusions) on charges without any, or with noticeable, anomalies could be used for the normal or reference class.

As expected, the data collected using more charges of the same steel grade and the same production technology led to a more stable normal class. The MD calculation and threshold calculation can be automatic, generally without human intervention. To use the MD as an outlier detector, we need only determine an additional threshold in terms of, e.g., the percentage of outliers for additional data and could automatically take some action in terms of additional report generation (e.g., ternary plots and/or notification for human supervision). The application of MDs in this case leads to an abundance of MDs obtained from a single sample (or charge in this case), since an MD is obtained for each nonmetallic inclusion. The abundance of data in the distribution space offers an excellent and diverse opportunity for differentiation. Perhaps the most obvious drawback of MDs is that they do not give insight into the metallurgical processes and chemistry involved in the formation of nonmetallic inclusions, which is contrary to established ternary plots. As shown in the paper (see Figures 8 and A1 and Figure A2 in Appendix A) the application of an MD combined with ternary plots extends the NMI data-analysis possibilities. Although the use of MD on NMI features for two-class separation (normal vs. abnormal) and NMI features for clustering according to their types stem from same data, their purposes and uses are very different.

\section{Conclusions}

Selected samples of three charges of scrap-based, Ti-stabilized, Cr-Ni-Mo, austenitic stainless steels in the form of hot-rolled steel plates were characterized. Based on automated metallographic analyses of the inclusions in representative microstructures (i.e., nonmetallic inclusions and segregations) a high-quality characterization in terms of steel cleanliness of the hot-rolled plates was possible. In addition to this, the classification of materials based on a calculation of the Mahalanobis distance (MD) between inclusions was possible.

The following conclusions can be drawn:

- $\quad$ The recycled FeTi-cored wire was the main source of elevated levels of impurities detected in the hot-rolled, Ti-stabilized stainless-steel plates.

- Insoluble impurities that are present in the FeTi wire for alloying of $\mathrm{Cr}-\mathrm{Ni}$-Mo stainless steel can greatly affect the final quality of the hot-rolled plates.

- Because of a high oxygen content in the used FeTi wire, the elemental Al could react with $\mathrm{Ti}_{\mathrm{x}} \mathrm{O}_{\mathrm{y}}$ to form complex, nonmetallic inclusions that were very stable at the fabrication temperature of the steel before continuous casting.

- The occurrence of $\mathrm{Mo}, \mathrm{S}, \mathrm{Pb}$, and $\mathrm{Bi}$ segregations was associated with the use of the recycled FeTi wire and the use of $\mathrm{MoS}_{2}$ in the mechanical preparation of the FeTi.

- In calculations of MDs, the steel charge with the smallest number of nonmetallic inclusions and segregations was set as a reference class. 
- $\quad \mathrm{MDs}$, as a measure of the difference between only two classes, offer some possibilities for the automatic detection of abnormalities in steel measured indirectly using the data obtained with the automatic detection of inclusions.

- However, a combination of metallographic and mathematical techniques is recommended.

- The selection of outlier inclusions based on their MDs and their back-representation into ternary diagrams gave relevant metallurgical information about the abnormalities.

- The advantage of this technique is that the calculations of the MD and the threshold can be fully automated.

Author Contributions: Conceptualization, F.V., F.T. and D.S.P.; methodology, F.V., F.T. and D.S.P.; software, F.V.; validation, F.V., F.T. and D.S.P.; formal analysis, F.V., F.T. and D.S.P.; investigation, F.V., F.T. and D.S.P.; resources, F.V., F.T., G.K. and D.S.P.; data curation, F.V., F.T., G.K. and D.S.P.; writing—original draft preparation, F.V., F.T. and D.S.P.; writing—review and editing, F.V., F.T. and D.S.P.; supervision, F.T. and D.S.P.; project administration, F.T. and D.S.P.; funding acquisition, F.V., F.T., G.K. and D.S.P. All authors have read and agreed to the published version of the manuscript.

Funding: The authors F.V., F.T. and D.S.P. acknowledge the financial support from the Slovenian Research Agency (research core funding of P2-0050 and P2-0132). This research was also funded by SIJ-Acroni, d.o.o., Jesenice.

Institutional Review Board Statement: Not applicable.

Informed Consent Statement: Not applicable.

Data Availability Statement: The data used to support the findings of this study are available upon request.

Acknowledgments: The authors are very grateful to the staff of the Laboratory of Metallography and especially to Tina Sever for her direct technical assistance.

Conflicts of Interest: The author declares no conflict of interest.

\section{Abbreviations}

Besides chemical formulae of compounds, the following abbreviations are used in the manuscript:

AISI American Iron and Steel Institute

AOD Argon oxygen decarburization

ASTM American Society for Testing and Materials

BSE Back-scattered electrons

BSI Back-scattered electron imaging

CE Circular economy

EAF Electric arc furnace

ECD Equivalent circular diameter

EDS Energy-dispersive spectroscopy

EOL End-of-life

FE-SEM Field emission scanning electron microscopy

GOST Gosudarstvennii Obscesoiuznii Standard (Russian)

ICP-OES Optical emission spectrometer with inductively coupled plasma

ISO The International Organization for Standardization

LF Ladle furnace

LN2 Liquid nitrogen

MD Mahalanobis distance

NMI Nonmetallic inclusion

OM Optical microscopy

VOD Vacuum oxygen decarburization

$\mathrm{Z} \quad$ Atomic number of a chemical element 


\section{Appendix A}

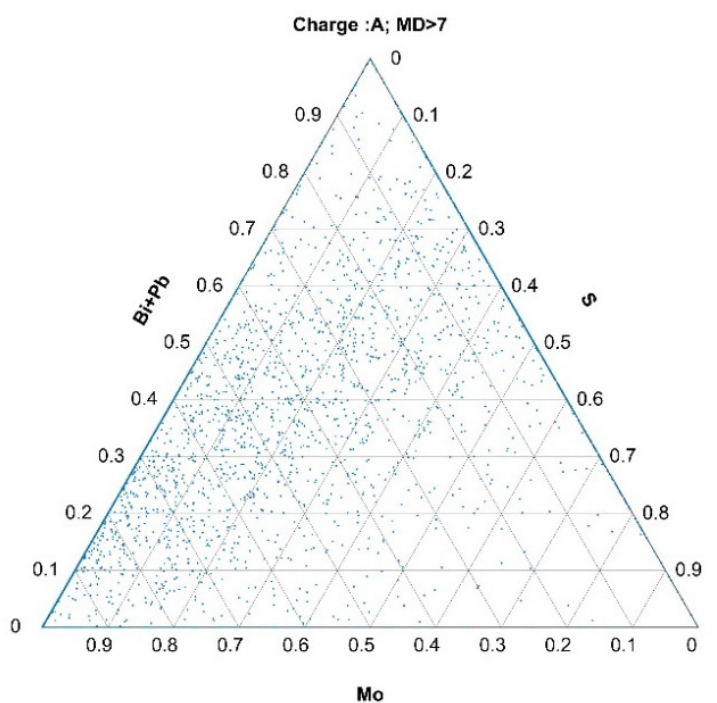

Charge :B; MD>7
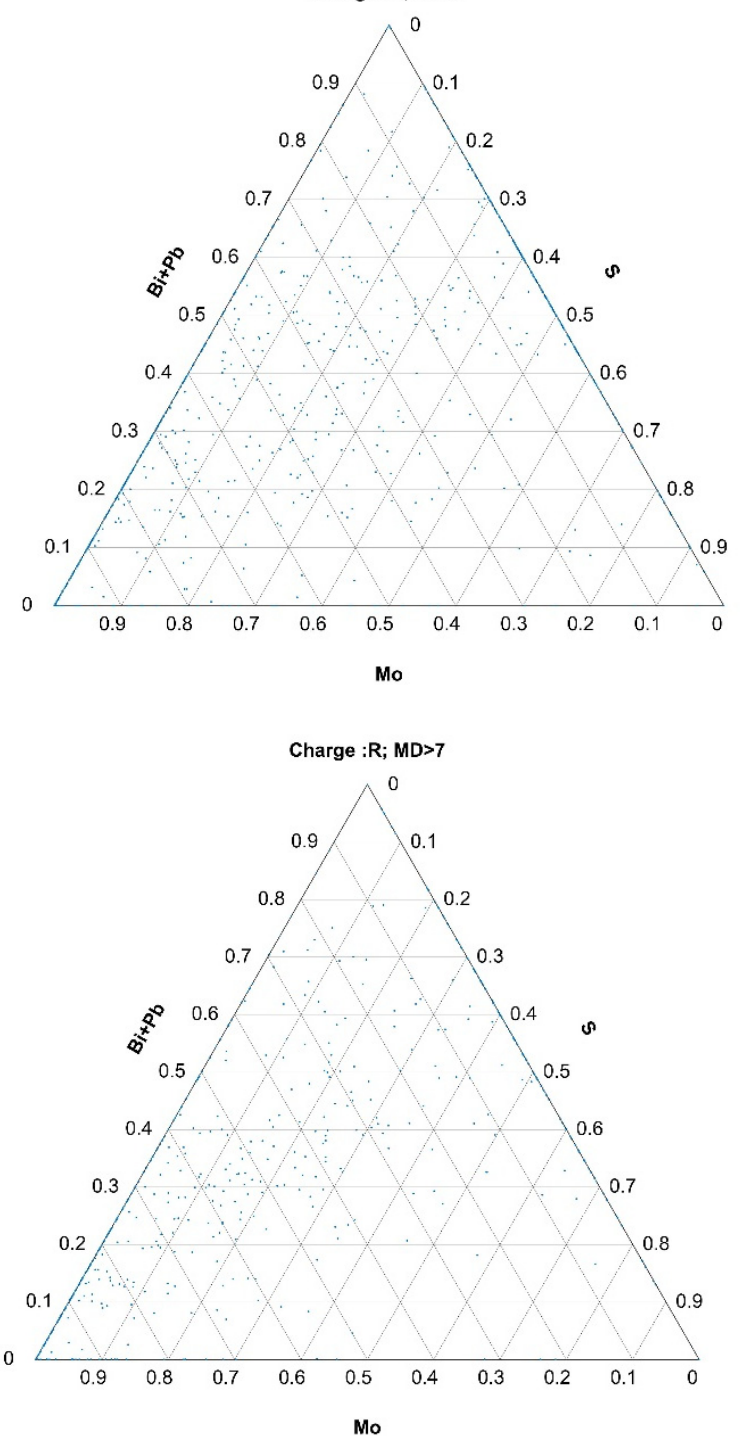

Figure A1. Inclusions classified as outlying (MD > 7) represented in a ternary diagram of Mo, $\mathrm{S}$, and $\mathrm{Bi}+\mathrm{Pb}$ for charges $\mathrm{A}, \mathrm{B}$, and $\mathrm{R}$. 

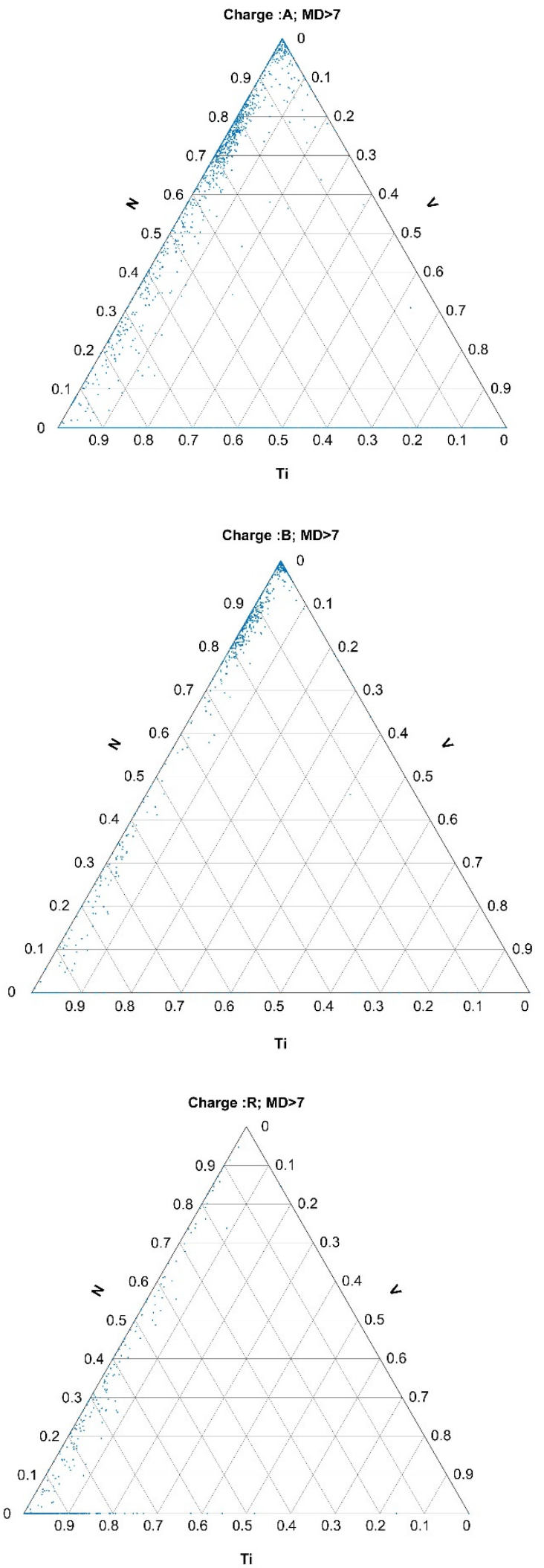

Figure A2. Inclusions classified as outlying (MD > 7) represented in a ternary diagram of $\mathrm{Ti}$, $\mathrm{V}$, and $\mathrm{N}$ for charges A, B, and R. 


\section{References}

1. Ryan, N.A.; Miller, S.A.; Skerlos, S.J.; Cooper, D.R. Reducing $\mathrm{CO}_{2}$ Emissions from US Steel Consumption by $70 \%$ by 2050 . Environ Sci. Technol. 2020, 54, 14598-14608. [CrossRef] [PubMed]

2. Ren, L.; Zhou, S.; Peng, T.; Ou, X. A review of $\mathrm{CO}_{2}$ emissions reduction technologies and low-carbon development in the iron and steel industry focusing on China. Renew. Sustain. Energy Rev. 2021, 143, 110846. [CrossRef]

3. Rieger, J.; Colla, V.; Matino, I.; Branca, T.A.; Stubbe, G.; Panizza, A.; Brondi, C.; Falsafi, M.; Hage, J.; Wang, X.; et al. Residue Valorization in the Iron and Steel Industries: Sustainable Solutions for a Cleaner and More Competitive Future Europe. Metals 2021, 11, 1202. [CrossRef]

4. Echterhof, T. Review on the Use of Alternative Carbon Sources in EAF Steelmaking. Metals 2021, 11, 222. [CrossRef]

5. Harvey, L.D.D. Iron and steel recycling: Review, conceptual model, irreducible mining requirements, and energy implications. Renew. Sustain. Energy Rev. 2021, 138, 110553. [CrossRef]

6. Ramadan, A.; Shash, A.Y.; El-Mahallawi, I.S.; Senk, D.; Mattar, T. Identification of copper precipitates in scrap based recycled low carbon rebar steel. Mater. Des. 2017, 120, 157-169. [CrossRef]

7. Sun, G.; Fan, D.; Tao, S. Identification of Antimony precipitates in Sb-bearing C-Mn steel. Metall. Mater. Trans. B 2021, 52, 576-579. [CrossRef]

8. Arh, B.; Tehovnik, F. The oxidation and reduction of chromium of stainless-steels in an electric arc furnace. Metalurgija 2011, 50, 179-182.

9. Yin, X.; Sun, Y.H.; Yang, Y.D.; Bai, X.F.; Deng, X.X.; Barati, M.; McLean, A. Inclusion evolution during refining and continuous casting of 316L stainless-steel. Ironmak. Steelmak. 2016, 43, 533-540. [CrossRef]

10. Yin, X.; Sun, Y.; Yang, Y.; Deng, X.; Barati, M.; McLean, A. Effect of alloy addition on inclusion evolution in stainless-steels. Ironmak. Steelmak. 2017, 44, 152-158. [CrossRef]

11. Yin, X.; Sun, Y.; Yang, Y.; Bai, X.; Barati, M.; McLean, A. Formation of inclusions in Ti-stabilized 17Cr austenitic stainless-steel Metall. Mater. Trans. B 2016, 47, 3274-3284. [CrossRef]

12. Steiner Petrovič, D. Kinetics of Arsenic Surface Segregation in Scrap-Based Silicon Electrical Steel. Metals 2021, 11, 1. [CrossRef]

13. Vasconcellos da Costa e Silva, A.L. Non-metallic inclusions in steels-Origin and control. J. Mater. Res. Technol. 2018, 7, 283-299. [CrossRef]

14. Ren, Y.; Wang, Y.; Li, S.; Zhang, L.; Zuo, X.; Lekakh, S.N.; Peaslee, K. Detection of non-metallic inclusions in steel continuous casting billets. Metall. Mater. Trans. B 2014, 45, 1291-1303. [CrossRef]

15. Wang, H.; Yu, P.; Zhou, X.; Wang, Y.; Lv, X. Three-dimensional stability diagram of Al-Mg-O inclusions in molten steel. J. Mater. Res. Technol. 2021, 12, 43-52. [CrossRef]

16. Bartosiaki, B.G.; Morales Pereira, J.A.; Bielefeldt, W.V.; Vilela, A.C.F. Assessment of inclusion analysis via manual and automated SEM and total oxygen content of steel. J. Mater. Res. Technol. 2015, 4, 235-240. [CrossRef]

17. Zhitenev, A.; Salynova, M.; Shamshurin, A.; Ryaboshuk, S.; Kolnyshenko, V. Database Clustering after Automatic Feature Analysis of Nonmetallic Inclusions in Steel. Metals 2021, 11, 1650. [CrossRef]

18. Cuartas, M.; Ruiz, E.; Ferreño, D.; Setién, J.; Arroyo, V.; Gutiérrez-Solana, F. Machine learning algorithms for the prediction of non-metallic inclusions in steel wires for tire reinforcement. J. Intell. Manuf. 2021, 32, 1739-1751. [CrossRef]

19. Acerinox Europa, S.A.U. Cr-Ni-Mo Austenitic Stainless-Steel ACX 240. Available online: https://www.acerinox.com (accessed on 13 September 2021).

20. Van Bennekom, A.; Wilke, F. Comparison between Stabilised and Low Carbon Austenitic Stainless-Steels. Available online: https:/ / www.edelstahl-rostfrei.de/fileadmin/user_upload/ISER/downloads/Stabilised_LowCarbonAust_EN.pdf (accessed on 1 October 2021).

21. Pande, M.M.; Guo, M.; Blanpain, B. Inclusion Formation and Interfacial Reaction between FeTi Alloys and Liquid Steel at an Early Stage. ISIJ Int. 2013, 53, 629-638. [CrossRef]

22. Gasik, M.; Dashevskii, V.; Bizhanov, A. Metallurgy of Ferrotitanium. In Ferroalloys. Topics in Mining, Metallurgy and Materials Engineering; Springer: Cham, Switzerland, 2020.

23. Zheng, D.; Li, J.; Shi, C.; Zhang, J.; Geng, R. Evolution of TiN and oxide inclusions in Ti-containing Fe-25Ni-15Cr alloy during electroslag remelting. ISIJ Int. 2020, 60, 1577-1585. [CrossRef]

24. Wegst, C.W. Stahlschlüssel_Key to Steel, 25th ed.; Verlag Stahlschlüssel Wegst GmbH: Marbach, Germany, 2019.

25. Baker, T.N. Titanium microalloyed steels. Ironmak. Steelmak. 2019, 46, 1-55. [CrossRef]

26. Li, J.; Cheng, G.; Ruan, Q.; Pan, J.; Chen, X. Formation and evolution of oxide inclusions in titanium-stabilized 18Cr stainless-steel. ISIJ Int. 2018, 58, 2280-2287. [CrossRef]

27. Bebbington, R.W. The role of ferroboron and ferrotitanium in steels: Production methods, quality aspects, and addition techniques. In Proceedings of the 1st Int Chromium Steels and Alloys Congress (INFACON 6), Cape Town, South Africa, 8-11 March 1992; SAIMM: Johannesburg, South Africa, 1992; Volume 2, pp. 263-267.

28. Pan, C.; Hu, X.; Lin, P.; Chou, K. Evolution of Inclusions after Cerium and Titanium Addition in Aluminum Deoxidized Fe-17Cr-9Ni Austenitic Stainless-steel. ISIJ Int. 2020, 60, 1878-1885. [CrossRef]

29. Pan, C.; Hu, X.; Lin, P.; Chou, K. Effects of Ti and Al addition on the Formation and Evolution of Inclusions in Fe-17Cr-9Ni Austenite Stainless-steel. Metall. Mater. Trans. B 2020, 51, 3039-3050. [CrossRef] 
30. Shah, S.J.; Henein, H.; Ivey, D.G. Microstructural characterization of ferrotitanium and ferroniobium. Mater. Charact. 2013, 78, 96-107. [CrossRef]

31. Xing, L.; Guo, J.; Li, X.; Zhang, Z.; Wang, M.; Bao, Y.; Zeng, F.; Chen, B. Control of TiN precipitation behavior in titanium-containing micro-alloyed steel. Mater. Today Commun. 2020, 25, 101292. [CrossRef]

32. Cheng, C.; Dou, Z.; Zhang, T. Mechanism of Melt Separation in Preparation of Low-Oxygen High Titanium Ferroalloy Prepared by Multistage and Deep Reduction. Metals 2020, 10, 309. [CrossRef]

33. Jiao, H.; Song, W.L.; Chen, H.; Wang, M.; Jiao, S.; Fang, D. Sustainable recycling of titanium scraps and purity titanium production via molten salt electrolysis. J. Clean. Prod. 2020, 261, 121314. [CrossRef]

34. Chang, Z.P.; Yan, W.L.; Nazish, F. A theoretical survey on Mahalanobis-Taguchi system. Measurement 2019, 136, 501-510. [CrossRef]

35. Ramlie, F.; Muhamad, W.Z.A.W.; Harudin, N.; Abu, M.Y.; Yahaya, H.; Jamaludin, K.R.; Abdul Talib, H.H. Classification Performance of Thresholding Methods in the Mahalanobis-Taguchi System. Appl. Sci. 2021, 11, 3906. [CrossRef]

36. Cui, S.; Hu, B.; Ouyang, B.; Zhao, D. Thermodynamic assessment of the Mo-S system and its application in thermal decomposition of $\mathrm{MoS}_{2}$. Thermochim. Acta 2018, 660, 44-55. [CrossRef]

37. Sales, M.G.; Herweyer, L.; Opila, E.; McDonell, S. MoS 2 impurities: Chemical identification and spatial resolution of bismuth impurities in geological material. Appl. Surf. Sci. 2020, 508, 145256. [CrossRef]

38. RamReddy, K.; Nandha Kumar, E.; Jeyaraam, R.; Janak Ram, G.D.; Subramanya Sarma, V. Effect of grain boundary character distribution on weld heat-affected zone liquation cracking behaviour of AISI 316Ti stainless-steel. Mater. Charact. 2018, 142, 115-123.

39. Tehovnik, F.; Vodopivec, F.; Celin, R.; Arzenšek, B.; Gontarev, J. Effect of $\delta$-ferrite, lead and sulphur on hot workability of austenitic stainless-steels with solidification structure. Mater. Sci. Technol. 2011, 27, 774-782. [CrossRef]

40. Shankar, V.; Gill, T.P.; Mannan, S.L.; Sundaresan, S. Solidification cracking in austenitic stainless-steel welds. Sadhana 2003, 28, 359-382. [CrossRef]

41. Liu, H.T.; Chen, W.Q. Research on recovery for adding low melting point metal bismuth to eco-friendly Bi-S based free cutting steel. Ironmak. Steelmak. 2014, 41, 355-359. [CrossRef]

42. Xie, J.; Fan, T.; Zeng, Z.; Sun, H.; Fu, J. Bi-sulfide existence in 0Cr18Ni9 steel: Correlation with machinability and mechanical properties. J. Mater. Res. Technol. 2020, 9, 9142-9152. [CrossRef]

43. Xie, J.; Li, J.; Li, Z.; Wu, L.; Zhang, P.; Fu, J. Forms of Bi-sulphide in 1215MS steel related to machining and mechanical performance Ironmak. Steelmak. 2021, 48, 927-935. [CrossRef]

44. Li, Z.; Wu, D. Effect of free-cutting additives on machining characteristics of austenitic stainless-steels. J. Mater. Sci. Technol. 2010, 26, 839-844. [CrossRef]

45. Kim, M.S.; Lee, H.J.; Chang, Y.W. The effect of Mn/S ratio on hot ductility of Bi bearing free cutting steels. In Key Engineering Materials; Nam, S.W., Chang, Y.W., Lee, S.B., Kim, N.J., Eds.; Trans Tech Publications Ltd.: Bäch, Switzerland, 2007; Volume 345-346, pp. 169-172.

46. Liu, H.T.; Chen, W.Q. Hot ductility of eco-friendly low carbon resulphurised free cutting steel with bismuth. Ironmak. Steelmak. 2014, 41, 19-25. [CrossRef]

47. Liu, H.; Yu, Y.; Chen, W.; Wang, Q.; Wang, G. Effect of Mn/S Ratio on the Hot Ductility of Eco-friendly Bi-S based Free Cutting Steel. High Temp. Mater. Processes 2014, 33, 553-561. [CrossRef]

48. Aiswarya, P.M.; Ghosh, S.; Ganesan, R.; Gnanasekaran, T. Phase diagram studies on ternary Bi-Mo-O system. J. Solid State Chem. 2020, 292, 121657. [CrossRef] 